January 2016

\title{
Irrational Investors and the Corporate Inversion Puzzle
}

Gregory R. Day

Oklahoma State University Spears School of Business

\section{Recommended Citation}

Gregory R Day, Irrational Investors and the Corporate Inversion Puzzle, 69 SMU L. REV. 453 (2016) https://scholar.smu.edu/smulr/vol69/iss2/6

This Article is brought to you for free and open access by the Law Journals at SMU Scholar. It has been accepted for inclusion in SMU Law Review by an authorized administrator of SMU Scholar. For more information, please visit http://digitalrepository.smu.edu. 


\title{
IRRATIONAL INVESTORS AND THE Corporate Inversion Puzzle
}

\author{
Gregory Day*
}

\begin{abstract}
Despite recent legislative and administrative efforts, U.S. corporations continue to engage in a controversial business strategy known as a "corporate inversion." A U.S. corporation performing an inversion acquires a foreign corporation and then, through a series of complex transactions, restructures in the foreign corporation's country. In light of the United States' burdensome corporate tax code, the inversion process allows formally American corporations to become taxable as a foreign entity, generating sizeable tax savings.

It is seldom noticed, however, that the inversion trend raises a significant corporate law puzzle regarding the misaligned incentives dividing directors and shareholders. From a corporate director's point of view, inversions are particularly attractive. This is because the process can be structured to reduce a company's tax rate while also lessening management's duty to comply with costly regulatory frameworks. For instance, inverted companies often reincorporate in countries with more management-friendly corporate governance statutes. Likewise, since U.S. exchanges subject foreign incorporated companies to less scrutinizing securities regulations, the inversion process can allow publicly traded companies to minimize costly disclosure, auditing, and corporate governance requirements.

But critically, inversions are puzzling from an investor's or shareholder's perspective. Since corporate regulations are generally thought to protect investors, why would an individual invest in a company that has deliberately sought out and reincorporated in a country that provides minimal shareholder protections? In fact, shareholders often vote in favor of, and thus authorize, the very transactions that limit their ability to acquire

* Assistant Professor, Oklahoma State University Spears School of Business. The author would like to thank his research assistants Kristen Dikeman of the University of Oklahoma College of Law, and Tylnn Childress and Snigda Gutha of the Oklahoma State University Spears School of Business. This Article benefited from insightful comments provided at the Sixteenth Huber Hurst Research Seminar in San Francisco, California, hosted by the University of Florida Warrington College of Business. The Article was also presented at the Academy of Legal Studies of Business' Annual Conference in Philadelphia, PA and the Southeastern Academy of Legal Studies in Business' (SEALSB) Annual Conference in Atlanta, GA. The author would like to thank all of the conferences' discussants for their invaluable comments as well as the SEALSB executive committee for awarding this manuscript the Best Paper Proceedings Award. Others who provided insightful comments and criticism include Robert Prentice, Robert Bird, Jack Wroldsen, Haskell Murray, and Mike Schuster.
\end{abstract}


information and enforce other shareholder rights. So why is the corporate migration trend booming if individuals should disfavor investing in inverted companies and shareholders should refuse to authorize them? Do individuals value the law? Using an original dataset and empirical analysis, this Article explores why individuals appear to ignore something as important-and as valuable - as the law.

\section{TABLE OF CONTENTS}

Introduction ...................................... 454

I. The Corporate Inversion ..................... 461

II. Shareholders Versus Management, and the Corporate Inversion: A Case Study of Mylan's Strange International Journey ................................. 465

III. The Law and Investors (Ir)rational Behaviors ......... 470

IV. The Inversion Process's Other Regulatory Consequences . . 474

A. Corporate Governance.......................... 474

B. Securities Law ............................... 477

C. Mergers and Antitrust ....................... 479

D. Regulatory Frameworks and Investors ........ 480

V. Empirical Analysis ............................ 481

A. Research Design............................ 482

B. Results ................................. 486

VI. Implications, Policies, and Suggestions............... 488

A. Investor Rationality? ..................... 488

B. What to Do About Inversions? .............. 491

C. International Competition for Corporate Laws

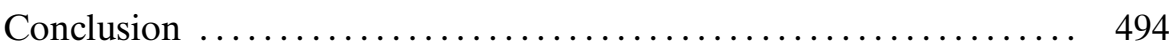

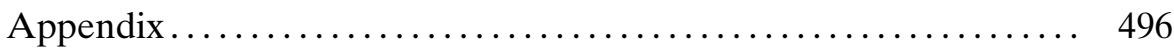

\section{INTRODUCTION}

A corporate inversion is an increasingly popular and controver-
sial business strategy used by U.S. corporations to reorganize as
a foreign entity. ${ }^{1}$ When a U.S. corporation performs an inversion it acquires a foreign corporation and then, through a series of complex transactions, reincorporates in the foreign corporation's country. ${ }^{2}$ The process is called an inversion because the acquiring company adopts the

1. See, e.g., Jeff Sommer, A Tax-Cutting Move That Pfizer Can Hardly Resist, N.Y. Times (Nov. 14, 2015), http://www.nytimes.com/2015/11/15/your-money/a-tax-cuttingmove-that-pfizer-can-hardly-resist.html?_r=2\%20(describing \%20the \%20popularity\%20 and $\% 20$ controversy $\% 20$ surrounding $\% 20$ the $\% 20$ recent $\% 20$ growth $\% 20$ of $\% 20$ corporate \%20inversions [https://perma.cc/4MNS-J2E3].

2. See generally Eric L. Talley, Corporate Inversions and the Unbundling of Regulatory Competition, 101 VA. L. REv. 1649, 1672-1699 (2015) (providing an excellent overall discussion of the corporate inversion process). 
target company's corporate identity in reverse of the usual process. ${ }^{3}$ And since inversions seldom require a change of physical location, the U.S. offices, assets, and employees of inverted firms typically remain located in the United States. ${ }^{4}$

The common explanation for the inversion trend is simple: U.S. companies would like to pay fewer taxes. ${ }^{5}$ The United States subjects American corporations to a notoriously burdensome tax code, including the Organisation for Economic Co-operation and Development's (OECD) highest corporate tax rate, as well as worldwide taxation. ${ }^{6}$ This latter feature taxes a U.S. corporation's entire global revenue stream, whereas most nations tax only what is earned inside their territorial borders. ${ }^{7}$ By inverting into a foreign entity, former U.S. corporations can escape important aspects of the U.S. tax code, generating sizeable tax savings.

Perhaps the most notable 2015 inversion was Pfizer's failed $\$ 150$ billion acquisition of Allergan, which the Treasury scuttled in 2016. ${ }^{8}$ An abridged list of inversions taking place in 2015 includes Medtronic's nearly $\$ 50$ billion inversion with Covidien, ${ }^{9}$ Coca-Cola Enterprises's acquisition of Iberian and German Coca-Cola bottling companies, ${ }^{10}$ and CF-OCI's $\$ 8$ billion merger. ${ }^{11}$ Johnson also announced that it intends to purchase and invert with Tyco not more than a few weeks into 2016; the surviving company is slated to become an Irish corporation named John-

3. See Lindsay Holst, What Are "Inversions," and Why Should You Care?, White House BlOG (July 24, 2014, 2:43 PM), https://www.whitehouse.gov/blog/2014/07/24/whatare-inversions-and-why-should-you-care [https://perma.cc/5TCA-DBQX] (defining an inversion as occurring when "a U.S.-based multinational with operations in other countries restructures itself so that the U.S. 'parent' is replaced by a foreign corporation-and usually one that's in a country with a lower tax rate than the United States").

4. See Hale E. Sheppard, Fight or Flight of U.S.-Based Multinational Businesses: Analyzing the Causes for, Effects of, and Solutions to the Corporate Inversion Trend, 23 Nw. J. INT'L L. \& Bus. 551, 555 (2003) (explaining that in an inversion "the corporate structure is basically turned upside down, with the newly-created foreign corporation becoming the parent. . . and the former domestic parent becoming a U.S. subsidiary of a foreign corporation. Hence, the term 'inversion." ").

5. See Mitchell A. Kane \& Edward B. Rock, Corporate Taxation and International Charter Competition, 106 Mich. L. REv. 1229, 1230 (2008) (noting that corporate inversions are "unabashedly all about tax reduction").

6. See Michael S. Knoll, The Corporate Income Tax and the Competitiveness of U.S. Industries, 63 TAX L. REV 771, 771-72 (2010) (stating that the only corporate tax rate higher than the United States is in Japan, though Japan has since lowered its tax rate).

7. See James R. Hines, Reconsidering the Taxation of Foreign Income, 62 TAx L. Rev. 269, 270 (2009).

8. Stephen Gandel, Why New Tax Inversion Rules Won't Stop Pfizer-Allergan Deal, Fortune (Nov. 20, 2015, 3:42 PM), http://fortune.com/2015/11/20/why-new-tax-inversionrules-wont-stop-pfizer-allergan-deal/ [https://perma.cc/2EDP-K2W6].

9. See David Crow, Medtronic: the tax inversion that got away, Fin. Times (Jan. 27, 2015, 11:20 AM), http://www.ft.com/intl/cms/s/0/ddcd9ad6-a5cf-11e4-ad3500144feab7de.html.

10. Arash Massoudi \& Lindsay Whipp, Coca-Cola bottlers agree three-way Europe merger, Fin. Times (Aug. 6, 2015, 12:09 PM), http://www.ft.com/intl/cms/s/0/10fd9c9e-3c2a11e5-bbd1-b37bc06f590c.html.

11. Ilan Brat, Fertilizer Maker CF to Buy Assets of Dutch Rival for $\$ 8$ Billion, WalL ST. J. (Aug. 6, 2015), http://www.wsj.com/articles/cf-industries-to-merge-with-parts-of-oci1438858580 . 
son Controls PLC. ${ }^{12}$

But as the inversion trend grows, so has the backlash against it. ${ }^{13}$ The problem is that inverted companies benefit from American laws and services while eroding the U.S. tax base at the same time. ${ }^{14}$ Corporate inversions also transfer capital abroad-almost $\$ 2.1$ trillion worth ${ }^{15}$ - where foreign nations can potentially gain the advantages of research and development, intellectual property innovation, and human capital growth. ${ }^{16}$ These negative effects have inspired boycott calls of tax-dodging U.S.

12. Bob Tita and Dana Mattioli, Johnson Controls, Tyco to Merge in Inversion Deal, WALL ST. J. (Jan. 25, 2016), http://www.wsj.com/articles/johnson-controls-tyco-to-merge-ininversion-deal-1453724828?mg=ID-wsj [https://perma.cc/58BF-KE7F].

13. See, e.g., Shane Zahrt, Ending Corporate Inversions: Past Failures, Continued Controversy and Proposals for Reform, 41 William Mitchell L. Rev. 1591, 1593 (2015) (after remarking that inversions are "exceedingly unpopular with the American public," the author offers solutions to prevent corporate inversions); Overseas 'tax inversions' are unpatriotic: Obama, N.Y. Post (July 26, 2014, 6:30 AM), http://nypost.com/2014/07/26/overseastax-inversions-are-unpatriotic-obama/ [https://perma.cc/6KHS-LU6K]. Others commentators assert that migrating companies are only acting rationally. The argument follows that American companies would remain incorporated in the U.S. if the corporate tax rate were lowered to a competitive level. See Joe Kennedy, Behind the Foreign Shopping Spree for U.S. Companies, WALL ST. J. (June 30, 2015), http://www.wsj.com/articles/ SB11760718815427544683404581068100290305890 [https://perma.cc/J624-6AYB] ("The Business Round Table and Ernst \& Young have calculated that the U.S. lost $\$ 179$ billion in assets of U.S.-based companies over the last decade through foreign acquisitions. If the top corporate rate had been lowered to $25 \%$ from $35 \%$ a decade ago, they estimate there would be 1,300 more U.S.-based companies today."). This camp also notes that assigning moral blame to migrating companies is unfair; so long as the United States orchestrates ways to tax the greatest amount possible-by, for instance, taxing internationally generated profits-it is fair game for companies to explore legal measures to reduce their tax burdens. Judge Learned Hand once noted that individuals are "not bound to choose that pattern which will best pay the Treasury. . ." Helvering v. Gregory, 69 F.2d 809, 810 (2d Cir. 1934), "[T]here is nothing sinister in so arranging affairs to keep taxes as low as possible." C.I.R. v. Newman, 159 F.2d 848, 850-51 (2d Cir. 1947).

14. See, e.g., Richard Trumka, Let's Call 'Corporate Inversion” What It Is: A Gaping, Unpatriotic Tax Loophole, Huffington Post (July 29, 2014, 9:50 AM), http:// www.huffingtonpost.com/richard-trumka/lets-call-corporate-inver_b_5629936.html [https:// perma.cc/23RP-2M9L] (arguing that companies are benefiting from "our legal system to protect their investments and patents, our education and training system to train their workers, our transportation system to get their products to market, our federally sponsored research, our military-but they want the rest of us to front their share of the bill").

15. Richard Rubin, U.S. Companies Are Stashing \$2.1 Trillion Overseas to Avoid Taxes, Bloomberg Business (Mar. 4 2015, 4:00 AM), http://www.bloomberg.com/news/ articles/2015-03-04/u-s-companies-are-stashing-2-1-trillion-overseas-to-avoid-taxes [https:// perma.cc/6KA9-AKGJ].

16. These additional negative externalities are perhaps more likely and more severe when an inverting corporation decides to relocate its headquarters abroad as well. See Omri Marian, Home-Country Effects of Corporate Inversions, 90 WAsH. L. Rev. 1, 13 (2015) ("There are several benefits in having a corporate headquarters located within a jurisdiction. For example, the national pride associated with having a well-known corporation headquartered within a jurisdiction may produce certain political benefits. In addition, a firm's headquarters may bring with it job creation and capital expenditure, resulting in positive economic effects in the jurisdiction in which the headquarters operate. Headquarters are also likely to 'generate learning and innovation, since research, development, and entrepreneurial activities' happen within corporate headquarters."). 
companies, ${ }^{17}$ President Obama described inversions as "unpatriotic"18 and the Daily Show's Jon Stewart warned of the "Inversion of the Money Snatchers." 19 Even the typically immobile federal government has promulgated a series of rules and regulations aimed at impeding the rate of new inversions. ${ }^{20}$

But despite the attention inversions receive, few have noticed that this trend raises a significant corporate law puzzle concerning the misaligned incentives dividing directors and shareholders. ${ }^{21}$ From a director's standpoint, inversions are quite appealing for reasons beyond reducing corporate taxes. Principally, a company's leadership may structure an inversion to diminish management's duty to comply with a number of burdensome corporate regulations. For instance, because U.S. securities laws are less demanding of foreign private issuers than U.S. corporations, a publicly traded company can structure an inversion to avoid costly disclosure, auditing, and corporate governance requirements. ${ }^{22}$ Inverted companies may also reincorporate in jurisdictions with more management-friendly corporate governance laws, neutralizing shareholder lawsuits, disclosure requirements, and external scrutiny. ${ }^{23}$ In this context, inverting gives corporate directors the perfect opportunity to escape the United States' onerous regulatory system. ${ }^{24}$

However, the inversion trend is quite puzzling from a shareholder's perspective. This is because corporate regulations are generally thought

17. See Renu Zaretsky, A Burger King Boycott? Senator takes a stand against corporate inversions, Christian SCI. Monitor (Sept. 2, 2014), http://www.csmonitor.com/Business/Tax-VOX/2014/0902/A-Burger-King-boycott-Senator-takes-a-stand-againstcorporate-inversions.

18. Overseas 'tax inversions' are unpatriotic: Obama, N.Y. Post (July 26, 2014, 6:30 AM), http://nypost.com/2014/07/26/overseas-tax-inversions-are-unpatriotic-obama [https:// perma.cc/6KHS-LU6K].

19. Inversion of the Money Snatchers, DaILy SHOw with JON STewart (July 30, 2014), http://thedailyshow.cc.com/videos/ehvwjx/inversion-of-the-money-snatchers [https:// perma.cc/5AHX-Y9KB].

20. See Arash Massoudi \& James Fontanella-Khan, US companies regain their appetite for tax inversion deals, FIN. TIMEs (June 15, 2015, 10:03 AM), http://www.ft.com/intl/cms/s/ 0/da02654e-12ad-11e5-8cd7-00144feabdc0.html.

21. Because shareholders have limited managerial rights, shareholders must depend upon directors and officers to advance their ownership interests; but at times, management harbors diverging interests from shareholders. See Richard A. Posner, Economic ANALYSIS OF LAW, at 557-58 (8th ed. 2010) (explaining that ownership rights and management rights are separated in American corporate law, giving shareholders few opportunities to operate the day-to-day operations of a company).

22. See Steven M. Davidoff, Regulating Listings in a Global Market, 86 N.C. L. Rev. 89, 130 (2007) (noting that foreign private issuers are classified under a different securities regime from American companies, requiring diminished disclosure requirements among other regulations).

23. Orsolya Kun, Corporate Inversions: The Interplay of Tax, Corporate, and Economic Implications, 29 DEL. J. CoRP. L. 313, 314 (2004) ("The conversion of a U.S. based multinational into a foreign corporation not only alters the tax exposure of the corporate group, but also changes the laws that govern intra-corporate relations.").

24. See, e.g., Michal Barzuza, Market Segmentation: The Rise of Nevada as a LiabilityFree Jurisdiction, 98 VA. L. REv. 935, 938-42 (2012) (noting that Nevada has sought to attract companies away from Delaware by eliminating director liability; the theory is that directors prefer jurisdictions where the costs of regulation are minimal). 
to protect shareholders and investors. ${ }^{25}$ Consider corporate governance laws; under almost all American corporate governance statutes, directors of U.S. corporations owe fiduciary duties to their shareholders, which shareholders may sue to enforce. ${ }^{26}$ Likewise, securities regulations require U.S. corporations to make regular disclosures that firms might otherwise choose to conceal from investors. ${ }^{27}$ So why would an individual invest in a company that has deliberately sought out and reincorporated in a country that poorly protects investors? ${ }^{28}$ In fact, since inverting requires shareholder approval, ${ }^{29}$ why would shareholders vote in favor ofand thus authorize - the very transactions that limit their ability to acquire information and enforce other shareholder rights? ${ }^{30}$ On the surface, it makes little sense why investors would ignore something as important, and as valuable, as the law.

The puzzling mindset and behaviors of investors is a recurring topic in legal scholarship. ${ }^{31}$ It was long believed that investors were "rational," meaning that they thoughtfully consider all aspects of a company before investing. ${ }^{32}$ This theory has fallen out of favor in lieu of a behavioral economics approach, which suggests that investors act in flawed and capricious manners. ${ }^{33}$ Although investors should value the law, they suffer

25. See, e.g., Donald C. Langevoort, The SEC, Retail Investors, and the Institutionalization of the Securities Markets, 95 VA. L. REv. 1025 (2009) ("The Securities and Exchange Commission thinks of itself as the investors' advocate.").

26. See Kelli A. Alces, Debunking the Corporate Fiduciary Myth, 35 J. CorP. L. 239, 243 (2009) (referring to fiduciary duties as a corporate governance tool meant to protect shareholder interests).

27. The SEC considers itself the advocate and protector of common investors. See What We Do, U.S. SEC \& ExсH. COMM'N, http://www.sec.gov/about/whatwedo.shtml [https://perma.cc/9AMC-GGM6].

28. See infra Section II (describing a series of Mylan transactions posing substantial questions about why shareholders consent to inversions).

29. Shareholders must almost always approve an inversion since an inversion requires a merger. For instance, Delaware laws require a board of directors that seeks to merge with another company to put the proposed merger to a vote of the shareholders. 8 Del C. $\$ 251$ (c).

30. Kun, supra note 23, at 364-65; see also Kane \& Rock, supra note 5, at 1236 (noting that the simplest way to reincorporate in another jurisdiction is through a shareholder vote).

31. See generally Donald C. Langevoort, Theories, Assumptions, and Securities Regulation: Market Efficiency Revisited, 140 U. PA. L. Rev. 851 (1992). See also Barbara Black, Behavioral Economics and Investor Protection: Reasonable Investors, Efficient Markets, 44 Loy. U. CHI. L.J. 1493, 1493-97 (2013) (discussing the use of investor behavior theories in securities litigation); Stephen J. Choi, Behavioral Economics and the Regulation of Public Offerings, 10 LewIS \& CLARK L. REv. 85 (2006) (explaining the use of behavioral economics in SEC regulations).

32. Tom C.W. Lin, Reasonable Investor(s), 95 B.U. L. REv. 461, 467 (2015) (“[T]he reasonable investor is generally understood to be the idealized, perfectly rational actor of neoclassical economics. The reasonable investor is presumed to operate rationally to maximize returns in the marketplace. Prior to making investment decisions, the reasonable investor is capable of reading and comprehending all the noise and signals in the marketplace that encapsulate formal disclosures, economic data, market trends, senseless speculation, and irresponsible rumors. As such, when given the requisite information, reasonable investors are able to properly price the risks and rewards of an investment.").

33. See Frederick C. Dunbar \& Dana Heller, Fraud on the Market Meets Behavioral Finance, 31 DEL. J. CoRp L. 455, 471-72 (2006) (explaining the emergence of the behav- 
from any number of cognitive disabilities limiting their capacity to make wise decisions. ${ }^{34}$ If this latter theory is correct, individuals might be investing in inverted companies because investors are, well, irrational.

Using empirical analyses and an original dataset, this Article tests these competing theories to determine whether investors and shareholders comprehend the potential dangers of inverting. The first hypothesis comes from behavioral economics: while investors should be skeptical of companies that structure inversions to dismantle shareholder protections, anecdotal evidence suggests that individuals irrationally ignore such dangers. ${ }^{35}$ The second hypothesis asserts that the complicated and poorly understood nature of inversions has created an illusion of illogical investing. After accounting for an inversion's many intricate parts, it may become apparent that investors deftly grasp the regulatory consequences of inverting. It could be that the benefits of a lower corporate tax rate outpace the potential harms of inverting. By statistically untangling the complexity of deal work, the following research explores how directors and shareholders interact when structuring an inversion.

In terms of contributions, this Article seeks to advance the inversion literature, which has developed slowly despite this transaction's popularity. ${ }^{36}$ Indeed, considering the obvious advantages of lowering a company's corporate tax rate, few have questioned why U.S. corporations pursue inverting. But this view ignores that corporations are comprised of heterogeneous actors-including directors, officers, and shareholders, who sometimes harbor diverging preferences. ${ }^{37}$ By treating inversions as an interaction between potentially adverse parties, this Article is likely the first to question why shareholders and investors support inversions. In doing so, the empirical analysis arrives at a fairly surprising conclusion: in contrast to most contemporary theories explaining investor behaviors, the shareholders involved in inversions generally understand the consequences of modifying corporate regulations. It seems sophisticated institutional investors play such a predominant leadership role in large corporate transactions that corporate directors must orchestrate inversions in a manner accounting for, and advancing, shareholder rights and preferences.

ioral finance theories relative to the historical dominance of the efficient market hypothesis).

34. See Stephen J. Choi \& A.C. Pritchard, Behavioral Economics and the SEC, 56 Stan. L. Rev. 1, 2 (2003) ("Not all investors are rational. Quite apart from the obvious examples of credulity in the face of the latest Ponzi scheme, there is no shortage of evidence that many investors' decisions are influenced by systematic biases that impair their abilities to maximize their investment returns.").

35. See infra Section II (using Mylan's example to illustrate the dangers potentially facing shareholders).

36. See Cathy Hwang, The New Corporate Migration; Tax Diversion through Inversion, 80 BROOK. L. REV. 807, 812 (2015) (describing inversions as "under-explored").

37. See Spencer Weber Waller, Corporate Governance and Competition Policy, 18 Geo. Mason L. Rev. 833 (2011) (remarking that "[c]orporate governance law addresses the misaligned incentives between officers and directors of publicly owned companies and their shareholders and how this can lead to the destruction of shareholder value"). 
In addition, understanding how investors approach inversions sheds valuable light on the debate between traditional and behavioral economics. In light of this Article's results, the question should be not be about which theory is superior, ${ }^{38}$ but rather about how scholars can use both approaches to explain investor phenomena. After all, considering that investors tend to favor inverting in strong regulatory climates, this raises questions about how and why some companies are still able to consummate value-stripping transactions. This Article finds that while traditional economics has greater explanatory power, behavioral economics makes sense out of anomalous observations. Thus, the following research helps to lay a foundation for integrating modern behavioral economics theories with more orthodox rationality work.

The statistical analysis also provides insight into the international competition for corporate charters. Corporate charters exist in an international market whereby countries promote their national business and corporate laws to attract wayward firms. ${ }^{39}$ How this competition is waged, though, likely foreshadows the evolution and direction of corporate law. ${ }^{40}$ If investors care little about the law, then firms will migrate to, and reincorporate in, whichever countries offer the lowest tax rates, relaxed securities regulations, and management-friendly corporate governance laws. ${ }^{41}$ But if investors actively prefer, and demand, strong legal systems, countries will respond with meaningful corporate statutes. ${ }^{42}$ The ensuing statistical analysis therefore helps to explain whether international corporate law is likely to develop as a race to the top or bottom. ${ }^{43}$

This Article proceeds in four parts. Section I overviews the typical inversion transaction and the laws governing it. Section II illustrates with a case study the ways in which inverting can empower corporate directors while harming shareholders. In this example, Mylan's shareholders might have decided to reject the company's Dutch inversion plans had they appreciated the transaction's dangers. Section III sheds light on why individuals invest in inversions, as well as why investors authorize them by

38. See, e.g., Alan Devlin \& Michael Jacobs, The Empty Promise of Behavioral Antitrust, 37 Harv. J.L. \& PuB. PoL'Y, 1009, 1023, 1052 (2014) (arguing that the inability of behavioral economics to advance antitrust scholarship is because behavioral economics lacks the rigors and explanatory power of traditional economics, and stating that its "tools are simply a patchwork of observed anomalies that behavioral scholars have not shown to be systemic in the field of industrial organization").

39. See Victor Fleischer, Regulatory Arbitrage, 89 TEx. L. REv. 227, 230 (2010) (noting that countries seek to attract companies using their legal regimes as a commodity).

40. See generally Lucian Arye Bebchuk \& Assaf Hamdani, Vigorous Race or Leisurely Walk: Reconsidering the Competition over Corporate Charters, 112 YALE L.J. 553 (2002) (discussing the competition over corporate charters and the significance of whether this competition is a race to the "top or the bottom").

41. See Jason M. Quintana, Going Private Transactions: Delaware's Race to the Bottom?, 2004 Colum. Bus. L. Rev. 547, 552-55 (2004) (explaining the "race to the top" versus "race to the bottom" debate, and how it influences behavior).

42. See Ehud Kamar, Beyond Competition for Incorporations, 94 Geo. L.J. 1725, 1726 (2006) ("As long as corporate decisionmakers prefer laws that maximize the value of the firm, jurisdictions will offer such laws.").

43. See Quintana, supra note 41, at 552-55. 
discussing the ways that investors cognize and respond to legal considerations. Section IV adds nuance and detail to international transactional work by explaining the regulatory decisions firms must consider when venturing beyond their country's borders-including corporate governance, tax, securities, and antitrust laws. Section V empirically examines investor behaviors in light of the various regulatory-adding or stripping transactions that publicly traded companies make. This study investigates whether investors and shareholders approach inversions irrationally or with thought and sophistication. To conclude, Section VI discusses the implications and potential policies of the statistical research.

\section{THE CORPORATE INVERSION}

Companies primarily cite the United States' tax code as their reason for inverting. ${ }^{44}$ As previously stated, the United States imposes the developed world's highest corporate tax rate. ${ }^{45}$ The United States is also one of the few countries to employ a worldwide taxation system, ${ }^{46}$ subjecting a U.S. corporation's entire global income stream to American taxation. ${ }^{47}$ Without worldwide taxation, foreign entities would not only enjoy their home country's lower tax rates but could also generate additional tax savings by transferring internationally generated revenue into even more lenient tax havens. ${ }^{48}$ These tax benefits are likely enough motivation for multinational U.S. corporations to relocate abroad, but as will be explained, incorporating abroad for foreign tax treatment is often difficult, costly, and sometimes impossible.

The U.S. government has promulgated several measures intended to prevent U.S. corporations from migrating abroad for tax purposes, most notably Section 7874 of the Internal Revenue Code (IRC) ${ }^{49}$ and two IRS notices issued in 2014 and 2015, respectively. ${ }^{50}$ During the 1980s and 1990s, a first wave of companies sought to lower their tax rates by rein-

44. See generally Talley, supra note 2 .

45. Brian Dumaine, The five countries with the highest corporate tax rate, FORTUNE (Nov. 21, 2014, 6:01 AM), http://fortune.com/2014/11/21/the-five-countries-with-the-highest-corporate-tax-rates/ (finding that the U.S. corporate tax rate can effectively be up to $40 \%$ when adding state taxes to the equation).

46. See Lawrence Lokken, Territorial Taxation: Why Some U.S. Multinationals May Be Less Than Enthusiastic About the Idea (And Some Ideas They Really Dislike), 59 SMU L. Rev. 751 (2006) ("The United States taxes domestic corporations on their worldwide incomes, with credit for foreign income taxes, but it only taxes foreign corporations on income from U.S. sources and on income effectively connected with U.S. trades or businesses.").

47. See I.R.C. §7701(a)(4); Kun, supra note 23, at 333 ("The United States has a worldwide tax system that taxes domestic corporations on income generated in the United States and abroad.").

48. See Joshua Simpson, Analyzing Corporate Inversions and Proposed Changes to the Repatriation Rule, 68 N.Y.U. AnN. SuRv. Am. L. 673, 674 (2013); see also Liz Hoffman, The Tax Inversion Wave Keeps Rolling, Wall ST. J. (July 7, 2015, 7:05 PM), http:// www.wsj.com/articles/horizon-pharma-at-the-nexus-of-taxes-and-deals-1436296946? $\mathrm{mg}=$ ID-wsj.

49. I.R.C. § 7874 (2016).

50. See I.R.S. Notice 2014-52 (Sept. 22, 2014); I.R.S. Notice 2015-79 (Nov. 19, 2015). 
corporating in tax havens ${ }^{51}$ because the U.S. tax code established a company's tax status by its place of incorporation. ${ }^{52}$ Due to the audacity of these naked tax-avoidance transactions, in 2004, Congress enacted Section 7874 as part of the Jumpstart Our Business Startups Act (JOBS Act), increasing the difficulty of becoming a taxable foreign entity. ${ }^{53}$

Under Section 7874, a U.S. corporation pursuing foreign tax treatment was required to execute a corporate inversion (also known as a "tax inversion"), which entailed acquiring and merging with a foreign company. ${ }^{54}$ For an inversion to be successful, Section 7874 placed strict limitations on the surviving entity's common ownership with its former U.S. corporation, otherwise known as "ownership continuity." 55 If less than $60 \%$ of the U.S. company's shareholders carried over to the new corporation, the newly inverted company would receive foreign tax treatment. ${ }^{56}$ If the newly inverted entity had more than an $80 \%$ ownership continuity with its old U.S. corporation, the inverted firm would remain subject to the U.S. tax code as a U.S. corporation. ${ }^{57}$ Most inverted firms fit the third category in which the inverted entity's common ownership falls between $60 \%$ and $80 \%$. While this category of inversion is considered successful, the company suffers negative tax consequences for a period of ten years. ${ }^{58}$ Upon satisfying either of $\S 7874$ 's $60 \%$ or $80 \%$ thresholds, an inverted corporation not only becomes a foreign entity for U.S. tax purposes but also assumes the acquired entity's corporate identity. However, there was one exception to Section 7874. A company that has "substantial business activities" in another country could invert in that country without penalty, regardless of its ownership continuity. ${ }^{59}$ Whether a company has substantial business activity is determined by the twenty-five percent test: ${ }^{60} 25 \%$ of the company's employees, asset value, total income, and employee compensation must be located in or attribu-

51. See Hwang, supra note 36 , at $821-23$.

52. See I.R.C. $\$ 7701(a)(4)$ (2016).

53. American Jobs Creation Act of 2004, Pub. L. No. 108-357, 118 Stat. 1418 (2004); see Tyler M. Dumler, Charging Less to Make More: The Causes and Effects of the Corporate Inversion Trend in the U.S. and the Implications of Lowering the Corporate Tax Rate, 13 U.C. Davis. Bus. L.J. 88 (2012).

54. See Daniel Shaviro, The David R. Tillinghast Lecture The Rising Tax-Electivity of U.S. Corporate Residence, 64 TAx L. Rev. 377, 377-78 (2011) ("Once a company is incorporated in the United States, however, escaping its status as a U.S. resident is difficult. It may require genuinely being purchased by new owners, such as a private equity fund or else a distinct foreign company with its own shareholders and managers.").

55. Talley, supra note 2 , at 1677.

56. Id.

57. I.R.C. $\S 7874(a)(2)(B)$, (b) (2016); Talley, supra note 2, at 1677.

58. I.R.C. $\$ 7874(\mathrm{~d})$; Hwang, supra note 36 , at 830 ("If ownership continuity is between $60 \%$ and $80 \%$, Section $7874 \ldots$ restricts the inverter in some way-for instance, by limiting the inverter's use of certain tax attributes to offset gains in the years after the inversion. In addition, the inverting corporation's ability to use net operating losses to reduce taxation of its inversion gain is limited.").

59. Hwang, supra note 36, at 830; see generally Joseph A. Tootle, The Regulation of Corporate Inversions and "Substantial Business Activities", 33 VA. TAX REV. 353 (2013).

60. See Hwang, supra note 36 , at 830. 
table to its inversion country. ${ }^{61}$

Despite Section 7874's $80 \%$ threshold, a number of U.S. companies have still been able to invert, prompting the IRS to issue its 2014 Notice, which made inversions even less profitable and harder to accomplish. ${ }^{62}$ The Notice added two principal anti-inversion measures, the first of which strengthened Section 7874's 80\% threshold. ${ }^{63}$ Previously, corporations concocted ways to satisfy the $80 \%$ threshold's letter but not necessarily its spirit. By paying "skinny down dividends," otherwise known as extraordinary dividends, U.S. corporations were able to reduce their asset totals to fall below the $80 \%$ level. ${ }^{64}$ The 2014 Notice, however, informed U.S. corporations that the Treasury would ignore extraordinary dividends, making the $80 \%$ threshold harder to achieve. ${ }^{65}$ The flipside of the skinny down was the "cash box," in which a foreign target company would account for assets that were absent from its regular business routine. ${ }^{66}$ This tax strategy helped target companies surpass the $20 \%$ requirement (whereas inverting U.S. corporations must get below the $80 \%$ barrier) until the IRS announced with the 2014 Notice that it would ignore assets in a firm's accounting when more than $50 \%$ of the assets were passive. ${ }^{67}$ In 2015, the IRS further clarified this rule, stating that any assets "stuffed" into a foreign corporation with the sole intent of satisfying the $20 \%$ threshold would be disregarded. ${ }^{68}$

The second measure within the 2014 Notice sought to eliminate a substantial non-tax benefit enjoyed by most inverted firms regarding foreign held capital. Because repatriating foreign-generated capital into the United States is typically a taxed transaction, U.S. corporations have long sought for ways to transfer foreign funds into the United States without paying the U.S. $35 \%$ corporate tax rate. ${ }^{69}$ Before the 2014 IRS Notice, an

61. Id.

62. See I.R.S. Notice 2014-52 (Sept. 22, 2014); Dumler, supra note 53, at 95.

63. See I.R.C. $\S 7874$. In addition, Subpart F seeks to limit the profitability of certain inversions. If a foreign corporation is owned by more than a majority of American shareholders, Subpart F allows the U.S. government to tax certain unrepatriated income. Simpson, supra note 48 , at 681 .

64. Zahrt, supra note 13, at 1608. (quoting Press Release, Dep't of the Treasury, Fact Sheet: Treasury Actions to Rein in Corporate Tax Inversions (Sept. 22, 2014), https:// www.treasury.gov/press-center/press-releases/Pages/j12645.aspx).

65. Fact Sheet: Treasury Actions to Rein in Corporate Tax Inversions (Sept. 22, 2014), https://www.treasury.gov/press-center/press-releases/Pages/j12645.aspx [https://perma.cc/ E928-XH8L].

66. $I d$.

67. Id.

68. See Fact Sheet: Additional Treasury Actions to Rein in Corporate Tax Inversions (Nov. 19, 2015), https://www.treasury.gov/press-center/press-releases/Pages/j10281.aspx [https://perma.cc/E928-XH8L].

69. I.R.C. $\$ 952$ (2016); Office of Tax Policy, Dep't Treasury, The Deferral of Income Earned Through U.S. Controlled Foreign Corporations: A Policy STUDY, ix (2000), http://www.treasury.gov/resource-center/tax-policy/Documents/subpartf.pdf; John T. VanDenburgh, Closing International Loopholes: Changing the Corporate Tax Base to Effectively Combat Tax Avoidance, 47 VAL. U. L. Rev. 313, 330 (2012) ("Earnings Stripping is a tax avoidance technique in which a U.S. corporation sets up a subsidiary in a low-tax country, and then the U.S. corporation uses its U.S. earnings and makes deductible payments to the subsidiary in the form of interest, royalties, or fees."). 
inverted company could access foreign capital, free of U.S. taxation, by having a subsidiary make loans or other non-payment transfers to its foreign parent company-after all, an inverted firm becomes a foreign entity upon completion of the inversion process. ${ }^{70}$ Therefore, an inverted firm could access foreign-held capital, whereas a U.S. corporation could not, by virtue of being reorganized abroad. This process became known as the "hopscotch loan."71 Other types of earnings-stripping or income-shifting transactions included fee payments, licensing deals, and rentals. ${ }^{72}$ This practice lasted until 2014 when the Treasury Notice announced that the IRS would consider hopscotch loans to be taxable dividends. ${ }^{73}$

After even more companies inverted in late 2015, including Pfizer and Allergan's announced, but ultimately unsuccessful record breaking $\$ 160$ billion acquisition, ${ }^{74}$ the Treasury sought to further frustrate corporate migrations by limiting the countries in which a firm could invert. Previously, companies pursuing an inversion were largely unrestricted in choosing where to reincorporate..$^{75}$ In selecting an inversion home, a U.S. corporation would have only to merge with two companies, the first being its primary foreign target company and the other a shell company incorporated in the inverting company's desired corporate home. So long as the inversion's total transaction satisfied Section 7874, the combination's surviving entity could assume the shell company's corporate identity. ${ }^{76}$ However, the 2015 IRS Notice ended this practice by requiring inverted firms to relocate to their primary merger partner's country of incorpora-

70. See I.R.C. § 956(c)(1)(C) (2016); 26 C.F.R. § 1.956-2(a)(1)(iii) (2016); see also Hwang, supra note 36, at 818 ("Prior to the Notice, domestic corporations that received loans from their controlled foreign corporations (CFCs) had to treat the loans as if the money had been repatriated to the United States as a dividend, and therefore had to pay taxes on that dividend.").

71. See generally Mike Patton, Will U.S. Government Succeed In Closing This Corporate Tax Loophole?, Forbes.com (Sept. 25, 2014, 11:57 AM), http://www.forbes.com/sites/ mikepatton/2014/09/25/congress-attempts-to-close-corporate-tax-loophole/.

72. See generally J. Clifton Fleming, Jr. et. al., Getting Serious About Cross-Border Earnings Stripping: Establishing An Analytical Framework, 93 N.C. L. REv. 673, 673-74 (2015); Kun, supra note 23, at 338; Hwang, supra note 36, at 818 ("Using a hopscotch loan, a corporation avoids those taxes by causing a CFC to make a loan to the domestic corporation's new foreign parent company, rather than to the domestic corporation directly. The promised regulations eliminate the benefits of hopscotch loans by making these loans subject to the same tax that would be owed if the CFC had made the loan directly to the domestic corporation.").

73. See Hwang, supra note 36 , at 818.

74. Antoine Gara, Pfizer's Tax Inversion Isn't A Miracle Drug: Just Ask Monsanto And Towers Watson, Forbes.com (Nov. 24, 2015, 2:18 PM), http://www.forbes.com/sites/ antoinegara/2015/11/24/pfizers-tax-inversion-isnt-a-miracle-drug-just-ask-monsanto-andtowers-watson/.

75. For example, before the 2015 IRS notice Mylan, a Pennsylvania corporation, was able to invert into a Dutch entity after merging with Abbott Laboratories, which was formally a Michigan corporation. Mylan executed the transaction by establishing a Dutch Shell corporation which was included, as a third party vehicle, into Mylan and Abbott's acquisition. This transaction structure allowed the new inverted Mylan to remerge as a Dutch corporation. New Moon B.V., Amendment No. 1 to Form S-4 Registration Statement (Dec. 9, 2014), http://www.sec.gov/Archives/edgar/data/1623613/ 000119312514437795/d813963ds4a.htm.

76. See id. 
tion, thereby nullifying the shell company's efficacy. ${ }^{77}$ This Notice frustrated several proposed inversions, including the CF/OCI acquisition, which had sought to become a United Kingdom corporation, but must now incorporate in the Netherlands. ${ }^{78}$

Although Section 7874 and the Treasury Notices were initially meant to halt most future inversions, the practical effect has only limited the availability of plausible inversion countries and partners, making these transactions harder to complete. ${ }^{79}$ After all, acquirers must now find such a specifically structured foreign target company that the surviving entity may satisfy either Section 7874 's $60 \%$ or $80 \%$ requirements. Nevertheless, many corporations with large overseas business segments still find inverting worthwhile, especially since the process can loosen other regulatory burdens such as securities, corporate governance, and antitrust requirements. ${ }^{80}$ With this in mind, the next Section examines how these regulatory-stripping transactions occurring during an inversion potentially harm shareholders while empowering directors.

\section{SHAREHOLDERS VERSUS MANAGEMENT, AND THE CORPORATE INVERSION: A CASE STUDY OF MYLAN'S STRANGE INTERNATIONAL JOURNEY}

The manner in which Mylan N.V. survived rival Teva's hostile takeover attempt illustrates two related points about inversions. The first is that corporate inversions implicate a fundamental problem of corporate law: corporate directors sometimes take actions serving their own preferences, despite owing fiduciary duties to act in their shareholders' best interests. ${ }^{81}$ In the inversion context, even though corporate regulations are meant to protect investors and shareholders, ${ }^{82}$ some directors favor inverting in countries that lack safeguards on par with U.S. regulations, potentially putting directors in conflict with their shareholders. ${ }^{83}$ In this case, Mylan's directors stripped its shareholders of rights and protections found under Pennsylvania law when they inverted the company into a

77. Fact Sheet: Additional Treasury Actions to Rein in Corporate Tax Inversions (Nov. 19, 2015), https://www.treasury.gov/press-center/press-releases/Pages/j10281.aspx.

78. Lisa Beilfuss \& Marie Beaudette, CF, OCI Amend Merger Agreement to Keep 'Inversion' Tax Benefit, WALl ST. J. (Dec. 21, 2015 9:38 PM), http://www.wsj.com/articles/cfoci-to-move-tax-residency-to-netherlands-1450704668.

79. See Shayndi Raice \& Dana Mattioli, Inversion Deals Retain Their Allure, WALL ST. J. (Aug 6. 2015, 9:28 PM), http://www.wsj.com/articles/inversion-deals-retain-their-allure-1438910884 (finding that the rate of companies inverting is increasing despite a temporary lull from regulatory changes).

80. See Section IV for a thorough analysis.

81. See Waller, supra note 37, at 833-34 (explaining that corporate law statutes are designed, in large part, to solve the problem posed when "managers and directors of large corporations often act in their own best interests rather than the best interests of the shareholders, who are the real owners of the company").

82. See Posner, supra note 21, at 557-58 (discussing the possibility that the interests of directors and shareholders may diverge).

83. See Kane \& Rock, supra note 5, at 1241 (explaining that "distortions to the market for corporate charters may arise where securing the tax surplus requires a corporation to locate in a suboptimal jurisdiction for corporate law purposes"). 
Dutch corporation. ${ }^{84}$ When Mylan's rival Teva sought to acquire Mylan, many Mylan shareholders preferred selling the company while Mylan's directors-likely fearing for their board positions-rejected Teva's bid. ${ }^{85}$ Mylan's shareholders found themselves powerless to contest the Board's actions and the ensuing destruction of shareholder value. These events triggered important questions concerning the possible reasons why Mylan's shareholders consented to such a self-defeating transaction. ${ }^{86}$ Is Mylan an anomalous situation or representative of most corporate inversions?

As background, Mylan, Inc. was originally headquartered and incorporated in West Virginia (Old Mylan). ${ }^{87}$ In 2014, Old Mylan inverted, merging with the Japanese and French business segments (the Business) of Abbott Laboratories (Abbott Labs). ${ }^{88}$ Right before purchasing Abbott Labs, Old Mylan organized two subsidiary corporations-New Moon B.V., a Dutch entity, and Moon of PA, a Pennsylvania corporation-to serve as vehicles for Mylan's Dutch reincorporation. ${ }^{89}$ The transaction required Old Mylan's shareholders to approve inverting, which they did overwhelmingly, so that New Moon could acquire Abbott Labs' Business, Old Mylan, and Moon of PA, the latter two entities ceasing to exist. ${ }^{90}$ The surviving entity, New Moon, was then renamed "Mylan N.V.," replacing Old Mylan's stock with Mylan N.V.'s new shares in a one-to-one transaction. ${ }^{91}$ Each of Old Mylan's directors then filled Mylan N.V.'s board. ${ }^{92}$ The merger allowed Mylan to reincorporate and invert in the Netherlands, becoming taxable as a foreign entity. ${ }^{93}$ Although Mylan N.V. superficially resembles Old Mylan regarding the company's shareholder

84. See Ronald Barusch, Dealpolitik: Why Mylan Has a Leg Up in the Vote on Its Perrigo Bid, WALl ST. J. (July 10, 2015, 3:21 PM), http://blogs.wsj.com/moneybeat/2015/07/ 10/dealpolitik-why-mylan-has-a-leg-up-in-the-vote-on-its-perrigo-bid/ (noting that Mylan's board is able to use certain tools under Dutch law to win the Perrigo vote, despite the fact that the shareholders seem to disfavor the transaction).

85. See generally Gregory R. Andre, Tender Offers for Corporate Control: A Critical Analysis and Proposals for Reform, 12 Del. J. CoRP. L. 865, 866 (1987) ("Tender offers for corporate control improve the economic efficiency of the marketplace and enable shareholders to sell their shares to an offeror at a substantial premium over the market price. Potential acquirers, however, often face obstacles when attempting to tender their bids to target shareholders. Target management often opposes tender offers by engaging in a wide variety of defensive tactics to avoid the possibility of displacement in the wake of a hostile takeover. Shareholders, as a practical matter, are powerless to stern such abuse.").

86. Shayndi Raice \& Liz Hoffman, Mylan's Leverage to Resist Teva Deal Reveals Shift in Rules, WALl ST. J. (July 27, 2015, 7:20 PM), http://www.wsj.com/article_email/mylansleverage-to-resist-teva-deal-reveals-shift-in-rules-1438029585-IMyQjAxMTA1OTI1ODEy $\mathrm{ODg} 0 \mathrm{Wj}$.

87. About Us, Mylan.Com, http://www.mylan.com/en/company/about-us us (last visited, Jan. 4, 2016);

88. New Moon B.V., Amendment No. 1 to Form S-4 Registration Statement (Dec. 9 2014), http://www.sec.gov/Archives/edgar/data/1623613/000119312514437795/ d813963ds4a.htm [https://perma.cc/2FVT-VH85].
89. Id.
90. Id.
91. $I d$.
92. Id.
93. Id. 
and board structures, Mylan N.V.'s internal governance was substantially reorganized under the Netherlands's more lenient corporate regulatory regime. By virtue of inverting into a Dutch entity, reports suggest that Mylan's directors sought out the Netherlands management-friendly Dutch regulatory regime; this is the hidden side of corporate inversions.

The first signs of conflict between Mylan's management and ownership surfaced soon after inverting when rival pharmaceutical company, Teva, sought to acquire Mylan. ${ }^{94}$ Faced with a hostile acquirer, Mylan's directors employed a notoriously "draconian" Dutch defensive measure known as a stichting. ${ }^{95}$ A stichting is an independent third-party trust, available only under Dutch law, that protects a target corporation from a hostile acquirer. ${ }^{96}$ In essence, a company may issue up to $50 \%$ of its preferred stock to a stichting, preventing a hostile acquirer from gaining majority control. ${ }^{97}$ The problem was that many Mylan shareholders favored accepting Teva's $\$ 40$ billion tender offer, yet were unable to effectuate a deal because Mylan's directors could use the company's stichting to reject almost any Teva bid. ${ }^{98}$ In fact, because it is so effective, a stichting would likely violate U.S. law if Mylan had still been incorporated in Pennsylvania, transgressing both U.S. securities and corporate governance regulations. ${ }^{99}$ By authorizing Mylan's Dutch inversion, Mylan's shareholders had this relinquished significant U.S. protections in favor of the Nether-

94. Id.

95. See Al Jones, Perrigo blasts Mylan in latest defense of hostile takeover bid, MICHIGAN Live (Nov. 9, 2015, 5:00 PM), http://www.mlive.com/business/west-michigan/index.ssf/ 2015/11/perrigo_blasts_mylan_in_latest.html [https://perma.cc/X8BF-7S34].

96. See generally Shayndi Raice \& Margot Patrick, The Rise of the 'Stichting,' WALL ST. J. (Apr. 22, 2015, 12:15 PM), http://www.wsj.com/articles/the-rise-of-the-stichting-anobscure-takeover-defense-1429716204.

97. Steven Davidoff Solomon, Mylan's Dutch Takeover Defense Is in Nasdaq's Hands, N.Y. Times (June 11, 2015), http://www.nytimes.com/2015/06/12/business/dealbook/mylansdutch-takeover-defense-is-in-nasdaqs-hands.html?emc=eta1 (offering greater detail about stichtings as an ownerless shell trusts designed to be legally distinct from the beneficial corporation. A stichting is controlled by a board of directors who are supposed to be legally distinct from the corporation. However, the corporation typically retains sole control and discretion regarding).

98. See Steven Davidoff Solomon, A So-Called Independent Foundation Enters the Mylan-Teva Fray, N.Y. Times (July 23, 2015), http://www.nytimes.com/2015/07/24/business/ a-so-called-independent-foundation-enters-the-mylan-teva-fray.html?_r=0 ("Hoping to dissuade any shareholders who might prefer to go along with a Teva takeover, Mylan is making the argument that Teva is really not an option. It is sending the message that . . . the stichting will block it.").

99. See Jones, supra note 95. The problem was that Mylan is listed on Nasdaq, which proscribes companies from issuing dilutive shares to drown out hostile acquirers. Davidoff, supra note 98. In fact, Nasdaq rules required Mylan's board to obtain shareholder approval before "potentially" issuing shares in excess of $20 \%$ of the company's value, which Mylan failed to do. Id. ("Nasdaq also has a 'change of control rule,' which requires that any issue or potential issue of securities that would result in a change of control of the company must be preapproved by shareholders."). Professor Davidoff notes that Mylan could argue that its shareholders have already approved of the use of the stichting, and thus a greater than $20 \%$ stock issuance, when it voted in favor of the takeover merger with Abbott Laboratories, whereby the company became Dutch. This could implicitly mean that the shareholders approved the use of all measures, including a stichting, available under Dutch law. That said, Professor Davidoff is highly skeptical that this argument would be successful. Id. 
lands's more management-friendly corporate governance regime. It would soon become more apparent that Mylan's directors structured Mylan's reincorporation in additional ways to increase their power relative to shareholders.

Mylan's directors also used the inversion process to prevent a shareholder vote from unseating them. Most corporations keep directors accountable by allowing shareholders to call a special meeting in which shareholders may call a referendum on the board. ${ }^{100}$ Teva, as a $4.61 \%$ shareholder of Mylan, sought to call such a vote. ${ }^{101}$ However, Mylan's directors drafted a special voting mechanism into the company's Dutch articles of incorporation: if Mylan's shareholders successfully voted to remove the company's directors, the unseated directors reserved the right to select Mylan's new directors. ${ }^{102}$ In other words, even if Teva unseated the directors, Mylan's directors would be able to select loyal executives or even perhaps reappoint themselves. ${ }^{103}$ In light of this arrangement's impermissibility under U.S. law, Mylan's inversion appears to have helped Mylan's directors deprive shareholders of a critical accountability mechanism. ${ }^{104}$

In addition, Mylan's board allegedly violated their fiduciary duties by rejecting Teva's takeover offer. ${ }^{105}$ But under Dutch law, directors owe fiduciary duties to more parties than just their corporations and shareholders, including customers, government personnel, employees, and stakeholders. ${ }^{106}$ In fact, Mylan's board expressly stated that it might subordinate shareholder preferences below stakeholders. ${ }^{107}$ When re-

100. See generally Christopher Gulinello, The Retail-Investor Vote: Mobilizing Rationally Apathetic Shareholders to Preserve or Challenge the Board's Presumption of Authority, 2010 Utah L. Rev. 547, 551-52 (2010).

101. Ronald Barusch, Deal Politik: Tax Inversion Craze Casts Confusing Shadow Over U.S. Takeovers, Wall ST. J. (June 8, 2015, 11:55 AM), http://blogs.wsj.com/moneybeat/ 2015/06/08/dealpolitik-tax-inversion-craze-casts-confusing-shadow-over-u-s-takeovers/;

Steven Davidoff Solomon, Maneuvers and Dutch Defenses that May Complicate MylanTeva Takeover War, N.Y. Times (June 23, 2015), http://www.nytimes.com/2015/06/24/business/maneuvers-and-dutch-defenses-that-may-complicate-takeover-war.html?emc=eta1 ("Under Mylan's organizational documents, 10 percent of Mylan's shareholders can call a general meeting to remove the Mylan board. Teva already owns 4.61 percent and the hedge fund Paulson \& Company holds about the same, so this threshold might be easily met.").

102. See Barusch, supra note 84.

103. Id.

104. Solomon, supra note 101; see Raice \& Hoffman, supra note 86 ("At some companies, like Mylan, shareholders now have less leverage with management thanks to their new foreign home").

105. See Ed Silverman, Has Mylan Labs Been Stichting It to Shareholders? A Lawsuit Says 'Yes!', Wall ST. J. (Jul. 28, 2015, 10:05 AM), http://blogs.wsj.com/pharmalot/2015/07/ 28/has-mylan-labs-been-stichting-it-to-shareholders-a-lawsuit-says-yes/.

106. Raice \& Hoffman, supra note 86 (In contrast to American corporate law where a director owes fiduciary duties to shareholders, under Dutch Law, directors have fiduciary duties to stakeholders. "A Mylan spokesman said, 'Mylan certainly has always considered the interests of shareholders. But a core principle at Mylan is that shareholders benefit from a well-run business, and to run a business well, you need to focus on all of the stakeholders we touch on a daily basis, including customers, patients, employees, suppliers, creditors and communities." ").

107. Id. 
jecting Teva's offer, Mylan's Executive Chairman reportedly told Teva representatives "[t]his is a stakeholder company [now], not a shareholder company." 108 And since fiduciary duty claims are the premier means by which American shareholders are able to protect their ownership interests, it appears that Mylan's shareholders lost a critical safeguard during the company's inversion. ${ }^{109}$

Mylan's board may have also violated U.S. securities laws when it sought to acquire Perrigo as a means to block Teva's takeover. The merger with Perrigo appealed to Mylan's board because a surviving Mylan/Perrigo entity would have been too large for Teva to purchase. ${ }^{110} \mathrm{But}$ since Mylan's board needed shareholder approval to acquire Perrigo, the board's ability to ward off Teva likely depended on whether Mylan's shareholders voted in favor of a Perrigo acquisition. ${ }^{111}$ In hopes of winning this vote, Mylan's board issued a preliminary proxy statement invoking another management-friendly Dutch voting measure established in Mylan's inversion: the voting cut-off date. ${ }^{112} \mathrm{~A}$ cut-off date requires shareholders to inform a corporation's board of their intention to vote on a deal, either in person or by proxy, up to seven days beforehand. ${ }^{113}$ This mechanism of allowing Mylan's board to carry the vote likely would have disenfranchised U.S. shareholders unfamiliar with such a requirement. ${ }^{114}$ Mylan's stichting could have even supplied the extra votes needed by the board. ${ }^{115}$ Not only is this type of mechanism absent from U.S. corporate law, it also likely violates SEC proxy rules. ${ }^{116}$ Indeed, some observers asserted that Mylan's directors sought to suppress oppositional votes despite U.S. securities laws and their shareholders' apparent preference for a Teva deal.

In short, this case study details the alarm that Mylan's shareholders failed to express when Mylan's leadership proposed inverting. By reincorporating in the Netherlands, Mylan's board took actions-with which many shareholders sharply disagreed-that the company could not have effectuated under American law. From modifying fiduciary duties, using

108. Raice \& Hoffman, supra note 86.

109. Solomon, supra note 101; See Raice \& Hoffman, supra note 86 ("At some companies, like Mylan, shareholders now have less leverage with management thanks to their new foreign home").

110. Don't Cash in on Perrigo Yet, Upside Still Possible, Seeking Alpha (April 22, 2015, 5:27 PM), http://seekingalpha.com/article/3092166-dont-cash-in-on-perrigo-yet-upside-still-possible.

111. See Barusch, supra note 84 (stating that "The CEO of TEVA has said if [Mylan] shareholders approve the Perrigo bid, Teva will walk away from its pursuit of Mylan").

112. Id.

113. Id.

114. $I d$.

115. Id.

116. Id. ("The preliminary proxy materials say the cut-off date will be applied to attempts to revoke previously given proxies, but in my view restricting the ability of shareholders to revoke proxies at any time prior to a meeting raises significant issues under the Securities and Exchange Commission proxy rules, which apply because Mylan is U.S. listed and is treated for regulatory purposes as a domestic company. A person familiar with Mylan said the proxy revocation process complies with SEC requirements."). 
extraordinary defensive measures, and neutralizing shareholder votes, Mylan's directors structured the company's inversion to entrench themselves on the board. ${ }^{117}$ The question, then, is why did Mylan's shareholders agree to such a self-defeating inversion; was it irrational investing or simply a calculated gamble gone wrong?

\section{THE LAW AND INVESTORS' (IR)RATIONAL BEHAVIORS}

This Section explores the behavioral mindset of investors, shedding light on the reasons why shareholders appear to irrationally ignore the consequences of inverting and other regulatory-stripping transactions. In the Mylan example, the most logical explanation is that Mylan's shareholders failed to appreciate the ways in which Mylan's board could structure an inversion to undermine shareholder rights. But considering the sophistication and resourcefulness of institutional investors, it seems implausible that investors could have acted so recklessly. ${ }^{118}$

Helping to explain the lack of rationality underlying the inversion puzzle is a few decades' worth of legal scholarship that analyzes the thought processes of investors and shareholders. Investors were historically considered "rational," 119 meaning that they weighed all known aspects of a company before investing. ${ }^{120}$ And since institutional investors dedicate such significant resources to the evaluation processes, it was believed that stock prices quickly incorporate all known information about publicly traded companies. ${ }^{21}$ While some individuals do make investment errors, the odds of overvaluing or undervaluing a company are about equal; thus, investment mistakes "wash out" of stock prices, rendering markets that

117. See Jeffrey Sonnenfeld, Mylan, Valeant and Theranos: What the Heck, Biotech?, ForTune (Nov. 13, 2015, 10:42 AM), http://fortune.com/2015/11/13/theranos-valeant-mylan-governance-failures/ (mentioning that Mylan's antitakeover device effectively transferred company control from shareholders to an "entrenched" board).

118. See Brian G. Cartwright, Whither the SEC Now? 95 VA. L. REv. 1085, 1099 (2009) ("[O]ne thing is clear: sophisticated institutional investors are different from retail investors. Sophisticated institutional investors have highly professional staffs and substantial resources. They can hire outside firms and advisers. They have access to extensive information technology resources, and many have offices worldwide.").

119. See Robert Prentice, Whither Securities Regulations? Some Behavioral Observations Regarding Proposals for its Future, 51 Duke L.J. 1397, 1413 (2002) ("Conventional Law and economics assumes that individuals are rational, self-interested utility maximizers.").

120. See Scott Russell, Regulation Fair Disclosure: The Death of the Efficient Capital Market Hypothesis and the Birth of Herd Behavior, 82 B.U. L. REv. 527, 549-50 (2002) ("An 'efficient' market is defined as a market where there are large numbers of rational, profit-maximizers actively competing, with each trying to predict future market values of individual securities, and where important current information is almost freely available to all participants. . . 'Rational' and 'intelligent' market participants are an essential ingredient in Fama's hypothesis. 'Rational' is defined as '[h]aving or exercising the ability to reason.' 'Intelligent' is defined as '[s]howing sound judgment and rationality."').

121. See Ronald J. Gilson \& Reinier H. Kraakman, The Mechanisms of Market Efficiency, 70 VA. L. REv. 549, 551 (1984) (noting that "numerous studies demonstrate that the capital market responds efficiently to an extraordinary variety of information"). 
accurately value securities. ${ }^{122}$ This theory, the efficient market hypothesis $(\mathrm{EMH})$, gained such wide acceptance that it has become the foundation for most class action securities lawsuits. ${ }^{123}$ For instance, the United States Supreme Court in Basic v. Levinson ${ }^{124}$ ruled that plaintiffs could support a securities fraud claim without ever having come into contact with a fraudulent statement. ${ }^{125}$ The Court's logic was that since rational investing produces accurately priced markets, which fraud distorts, investors can suffer injuries from fraudulent statements by simply relying upon publicly available market prices. ${ }^{126}$ This theory became known as the "fraud on the market theory." 127 Applying the EMH to inversions, the decision whether to invest in an inverted company should be the product of all available, thoughtfully considered information.

But since the bankruptcies of Enron and Worldcom in 2001 and 2002, respectively, - as well as other financial disasters ${ }^{128}$ - the EMH has come under attack and fallen out of favor. ${ }^{129}$ How could a market that so accurately prices stocks make such gross errors? The indicia of accounting fraud and poor fundamentals were apparent, yet experts consistently misjudged these companies. ${ }^{130}$ Moreover, Enron and Worldcom were hardly isolated incidents, but instead segments of a larger, poorly valued market. ${ }^{131}$ And considering the EMH's apparent inability to reflect reality, several Supreme Court Justices seem eager to eliminate notions of

122. Id. at 581 ("Although individual traders will attach biased weights because each knows only a fraction of the relevant information, the cumulative weights will be unbiased unless trading volume is itself skewed toward the views of one set of uninformed traders. In this respect, unsystematic bias 'washes out' over trading in the same way that unsystematic risk 'washes out' in a diversified portfolio.").

123. See, e.g., id. at 549 ("Of all recent developments in financial economics, the efficient capital market hypothesis has achieved the widest acceptance by the legal culture"); Jill E. Fisch, The Trouble with Basic: Price Distortion after Halliburton, 90 WAsH. U. L. REv. 895, 896-98 (2013) (noting the central role of efficient markets within the "fraud on the market theory" in securities class actions, as codified by Basic); Russell, supra note 120, at 550 (explaining the function of an efficient market as when "competition among the many intelligent participants leads to a situation where, at any point in time, actual prices of individual securities already reflect the effects of information based both on events that have already occurred and on events which, as of now, the market expects to take place in the future. In other words, in an efficient market at any point in time the actual price of a security will be a good estimate of its intrinsic value.").

124. 485 U.S. 224 (1988)

125. See id. at 241-42.

126. Id. at 241 (quoting Peil v. Speiser, 806 F.2d 1154, 1160-1161 (3d. Cir. 1986)).

127. Id.

128. See, e.g., Janet Morrissey, Credit Default Swaps: The Next Crisis?, Time (Mar. 17, 2008), http://content.time.com/time/business/article/0,8599,1723152,00.html.

129. See Donald C. Langevoort, Taming the Animal Spirits of the Stock Markets: A Behavioral Approach to Securities Regulation, 97 Nw. U. L. Rev. 135, 136 (2002) (describing how the Enron bankruptcy caused legal scholars to reconsider the efficient market hypothesis).

130. Id. at 135-36 ("To a skeptic about the stock markets, the Enron debacle comes as no surprise. . The market fell in love with the company and, like many lovers, was far too slow to realize that the object of devotion was cheating.").

131. See, e.g., Adam J. Levitin \& Susan M. Wachter, Explaining the Housing Bubble, 100 GEO. L.J. 1177 (2012) (seeking to explain an even greater financial crisis based upon poor investing: the housing crisis leading to the "great recession"). 
investor rationality from securities litigation. ${ }^{132}$ In Halliburton Co. v. Eric P. John Fund, Inc., 133 the concurrence remarked that "overwhelming empirical evidence' now suggests that even when markets do incorporate public information, they often fail to do so accurately." 134

Behavioral economics, which combines aspects of psychology and traditional economics, is especially critical of the EMH. ${ }^{135}$ The behavioral economics literature asserts that people are irrational; they are not randomly irrational, but instead respond to stimuli pathologically, causing systematic over or under estimation of risk. ${ }^{136}$ For instance, studies show that investors value the market more optimistically when the weather is pleasant. ${ }^{137}$ Other examples include overestimating one's own abilities, status quo bias, reliance on heuristics, and confirmation bias. ${ }^{138}$ The most influential behavioral economics concept is loss aversion, which suggests that investors become overly risky in the face of losses, while too conservative otherwise. ${ }^{139}$

Perhaps behavioral economics can shed light on the inversion trend. Consider prior studies finding that people become more likely to adopt copycat behaviors - despite whether such behaviors are counterproductive or not-when others appear to profit from bending or breaking the rules. ${ }^{140}$ The key is that before making investment decisions, individuals tend to encounter voluminous amounts of information which must be re-

132. See Halliburton Co. v. Eric P. John Fund, Inc., 134 S.Ct. 2398, 2421 (2013) (Thomas, J., concurring) ("As it turns out, even 'well-developed' markets (like the New York Stock Exchange) do not uniformly incorporate information into the market prices with high speed."). See generally Charles R. Korsmo, Market Efficiency and Fraud on the Market: The Danger of Halliburton, 18 Lewis \& Clark L. Rev. 827, 830 (2014) (noting that Justice Alito's concurrence in Amgen suggests that Justices Alito, Scalia, and Thomas would like to overturn Basic based upon the faulty foundation of the efficient market hypothesis).

133. 134 S.Ct. at 2421.

134. Id. at 2421 (alterations in original).

135. See generally Donald C. Langevoort, Theories, Assumptions, and Securities Regulations: Market Efficiency Revisited, 140 U. PA. L. REV. 851 (1992) (offering a good primer discussing the relationship between rationality based investor theories and behavioral economics).

136. See Tom C. Lin, Reasonable Investor(s), 95 B.U. L. Rev. 461, 468-72 (2015) (reviewing evidence that investors do not actually act rationally but are instead susceptible to certain psychologically deficient investing processes); see also Choi \& Pritchard, supra note 34; Prentice, supra note 119.

137. Adi Osovsky, The Curious Case of the Secondary Market with Respect to Investor Protection, 82 TenN. L. Rev. 83, 128 (2014) ("It has become evident that even mood and emotions are dominant in the decision making processes of investors. Indeed, even the weather affects investment decisions.").

138. Tom C. Lin, A Behavioral Framework for Securities Risk, 34 Seattle U. L. Rev. 325, 341-48 (2011).

139. Id. At 342-43 ("Individuals are loss averse. They do not assign static values to objects; and when they give up or lose something. . . The negative impact of a loss is greater than the positive impact of an equal gain."); see generally Devlin \& Jacobs, supra note 38, at $1019-21$.

140. See Fred C. Zacharias, Steroids and Legal Ethics Codes: Are Lawyers Rational Actors?, 85 Notre Dame L. Rev. 671, 688 (2010) (mentioning the concept of the "cheater herd" and referring to groups of supposedly rational actors who become more likely to bend the rules when others appear to be cheating). 
duced to understandable and digestible portions. ${ }^{141}$ One technique is to follow the crowd; research shows that, under certain circumstances even sophisticated institutional investors ignore objective analyses in favor of peer mimicking. ${ }^{142}$ The urge to replicate others may become especially overwhelming when the masses appear to be cheating. ${ }^{143}$ One article explained the concept of "herd cheating," analogizing baseball's steroids scandal with unethical lawyering. ${ }^{144}$ Both phenomena involve those driven to cheat by a perception that others are profiting from breaking the rules. ${ }^{145}$ The interesting conclusion is that individuals sometimes cheat even if the strategy produces a worse result than following the rules, and thus, could be considered irrational. ${ }^{146}$

In fact, there was an illustrative story from the Petrified National Forest in northeastern Arizona. For some time, park visitors have been taking home pieces of petrified wood, depleting the park of its namesake.147 In hopes of reducing theft, park officials posted signs informing visitors about the harms caused by thievery. ${ }^{148}$ The strategy not only failed to prevent theft but resulted in tripled theft rates wherever the signs were posted. ${ }^{149}$ As it turns out, when people appear to gain a benefit from cheating, including petrified wood thievery, observers become more likely to deviate from fair play and replicate the rule breakers. ${ }^{150}$

Perhaps with inversions, investors and shareholders are irrationally willing to invert because of the popularity and perceived illicitness of the transaction. The amount of information available about publicly traded companies is so great that investors seldom seem to consider the regula-

141. See Stephen M. Bainbridge, Mandatory Disclosure: A Behavioral Analysis, $68 \mathrm{U}$. Cin. L. Rev. 1023 (2000) (arguing that a key determinant of herd behavior is incomplete information. "Herding can. . . be seen as a response to bounded rationality and information asymmetries. Under conditions of complexity and uncertainty, actors who perceive themselves as having limited information but can observe the actions of presumptively betterinformed persons may attempt to free-ride by following the latter's decisions.").

142. See Arthur E. Wilmarth, Jr., The Transformation of the U.S. Financial Services Industry, 1975-2000: Competition, Consolidation, and Increased Risks, 2002 U. ILl. L. Rev. 215,349 (2002) (describing the propensity of institutional investors to engage in herd behaviors); Donald C. Langevoort, Selling Hope, Selling Risk: Some Lessons for Law from Behavioral Economics about Stockbrokers and Sophisticated Customers, 84 CAL. L. REv. 627, 643-49 (1996).

143. Zacharias, supra note 140 , at 688 (remarking that people tend to pathologically follow "the cheater herd in situations in which financial self-interest is particularly strong, when the cheaters so dominate their field that rule violations are necessary in order to compete, or when it is unclear that obedience to the rules will have meaningful benefits, reputational or otherwise").

144. Id.

145. Id.

146. See Deven R. Desai, Bounded by Brands: An Information Network Approach to Trademarks, 47 U.C. DAvis L. REv. 821, 837-38 (2014) (describing the irrationality of herd behavior in the trademarks context).

147. Stephen J. Dubner, Riding the Herd Mentality: A New Freakonomics Podcast, Freakonomics: The Hidden Side of Everything (Jun. 21, 2012, 9:01 AM), http:// freakonomics.com/2012/06/21/riding-the-herd-mentality-a-new-freakonomics-radio-podcast/.

148. Id.

149. Id.

150. Id. 
tory consequences of inverting. If a critical mass of individuals invest in "cheating" companies, this could inspire others to follow suit, thus ignoring possible dangers. In other words, investors may be irrationally drawn to companies that play fast and loose with the rules, for example, by investing in Caribbean tax havens.

Therefore, it is possible that investors and shareholders make calculated gambles that an inversion's lower corporate tax rate outweighs its attendant regulatory dangers. That said, behavioral economics may better explain the reasons why corporate inversions fail to deter investors-people appear almost hardwired to make poor investment decisions. Before Section V empirically tests whether investors appreciate the legal and regulatory ramifications of inverting, Section IV details the additional legal and regulatory frameworks implicated by inversions. A major point is that directors can quietly manipulate an inversion's structure to either protect or harm shareholder interests via a number of regulatory adding or stripping transactions.

\section{THE INVERSION PROCESS'S OTHER REGULATORY CONSEQUENCES}

This Section briefly explores how companies may structure inversions to generate additional regulatory benefits or harms, depending on one's perspective. As mentioned, inversions are motivated by the regulatory advantages that foreign reincorporation provides, chief among them is a foreign tax rate. ${ }^{151}$ But in doing so, migrating companies can also modify the manner in which they must comply with other regulatory frameworks. ${ }^{152}$ Not only can this process lower compliance costs, ${ }^{153}$ it may also alter the relationship between a company's directors and shareholders-possibly to the shareholder's detriment. ${ }^{154}$ The following illustrates the regulatory considerations, tradeoffs, and obstacles that companies encounter when structuring an inversion and its hidden effects on the director-shareholder relationship. The primary regulatory frameworks, besides taxes, inverted companies may modify include corporate governance, securities, and antitrust compliance.

\section{A. Corporate Governance}

The jurisdiction in which a company inverts-and thus reincorporates-has just as salient implications for its corporate governance struc-

151. See Fleischer, supra note 39, at 229.

152. See, e.g., Chris Brummer, Stock Exchanges and the New Market for Securities Laws, 75 U. CHI. L. REv. 1435, 1438 (2008) (finding that countries can attract companies using their securities law; "stock exchanges are increasingly poised to operate as sellers of both domestic and foreign law").

153. See generally Fleischer, supra note 39, at 238 ("The government imposes regulatory costs on transactions in the form of taxes, securities-law disclosure requirements, antitrust constraints, environmental-compliance obligations, and so on.").

154. See supra Section II (discussing how Mylan orchestrated its inversion, likely to the shareholders' disadvantage). 
ture as its tax rate. By virtue of inverting and reincorporating, a company becomes subject to its new jurisdiction's corporate governance statute, which limits the ways it may exercise various corporate powers and structures internal affairs. For instance, U.S. corporations must perform certain non-optional activities, such as calling annual meetings, electing directors to the board, and holding shareholders votes. ${ }^{155}$ Importantly, under the "internal affairs doctrine," a U.S. company has almost complete freedom to incorporate in whichever jurisdiction it prefers, giving U.S. companies a large selection of corporate governance regimes from which to choose. ${ }^{156}$ The best-known corporate body of law belongs to Delaware, which non-coincidentally is home to more Fortune 500 companies than all other jurisdictions combined. ${ }^{157}$ While a greater review of corporate law's efficacy can be found elsewhere, ${ }^{158}$ Delaware's dominance is thought to be attributable to the state's keenly developed corporate body of law and court system. ${ }^{159}$

The issue is that companies considering an inversion face important decisions regarding potential corporate governance structures. Because companies must reincorporate wherever they invert, an inverted company becomes subject to its tax haven's corporate governance laws. ${ }^{160}$ Commentators suggest that this creates a tradeoff between selecting an optimal corporate governance structure or tax rate. ${ }^{161}$ For example, a company incorporated in a reputable corporate governance jurisdiction, such as Delaware, must necessarily abandon those benefits after inverting. ${ }^{162}$

Importantly, a company's site of incorporation has substantial implications for its director/shareholder relationship. Perhaps Delaware law's most salient benefit concerns how the state balances the competing interests between shareholders and directors. ${ }^{163}$ This problem becomes especially acute when a hostile takeover bid pits shareholders against

155. See, e.g., 8 Del. C. $\S 211$.

156. David M. Wilson, Climate Change: The Real Threat to Delaware Corporate Law, Why Delaware Must Keep a Watchful Eye on the Content of Political Change in the Air, 5 EnTrepreneurial Bus. L.J. 481, 482 (2010).

157. Curtis Alva, Delaware and the Market for Corporate Charters: History and Agency, 15 Del J. Corp. L. 885, 886-87 (1990).

158. See, e.g., John F. Coyle, Business Courts and Interstate Competition, 53 WM. \& MARY L. Rev. 1915, 1925-26 (2012) (discussing the dominance of Delaware in the market for corporate charters).

159. In fact, defensive measures can bolster a firm's value because a hostile acquirer must raise its offer to surpass the Unocal standard. See Revlon Inc. v. MacAndrews \& Forbes Holdings, Inc., 506 A.2d 173, 185 (Del. 1986); see also Alva, supra note 157, at 89394 (citing Roberta Romano, The State of Competition Debate in Corporate Law, 8 CARDozo L. Rev. 709 (1987); Roberta Romano, Law as a Product: Some Pieces of the Incorporation Puzzle, 1 J.L. ECON. \& ORG. 225, 241 (1985)).

160. Kun, supra note 23, at 313.

161. Kane \& Rock, supra note 5, at 1230.

162. Id. at 1236-37.

163. See David G. Yosifon, The Law of Corporate Purpose, 10 Berkeley Bus. L.J. 181, 200-203 (2013). 
directors. ${ }^{164}$ Although Delaware directors have "unflinching" duties to act in their shareholders' best interests, shareholders often favor hostile takeovers and the premium payments that acquirers offer, while directors fear losing lucrative board positions. ${ }^{165}$ The balance struck by Delaware provides corporate directors with the leeway to resist hostile takeovers using defensive measures, so long as the measures ostensibly increase firm value. ${ }^{166}$ Indeed, defensive measures benefit shareholders to the degree that they force a hostile acquirer to increase its tender offer, bolstering the target firm's value. To balance whether a defensive measure aids shareholders or entrenches directors, pursuant to Delaware's Unocal standard, ${ }^{167}$ directors may only use defensive measures that are proportional to the threat posed by a hostile acquirer. ${ }^{168}$ Combined with Delaware's lenient business judgment rule, directors seldom face liability. ${ }^{169}$ But when a takeover overture becomes significant, or almost imminent, a director's duties change; directors must then attempt to sell the company for as close to its greatest possible value. ${ }^{170}$ Delaware has thus balanced director and shareholder interests, whereby shareholders can expect maximum value, yet directors may act with minimal fear of liability.

In contrast, other jurisdictions operate more pro-management or proshareholder corporate governance statutes. For instance, some European nations disfavor hostile takeovers, making those jurisdictions particularly attractive to some directors. ${ }^{171}$ And while the fiduciary duties owed to shareholders are a hallmark of American corporate law, directors in many European countries owe fiduciary duties to non-equity actors including employees and stakeholders. ${ }^{172}$ Therefore, expanding the scope

164. See Hanson Trust PLC v. ML SCM Acquisition Inc., 781 F.2d 264, $277-78$ (2d. Cir. 1987) ("A director's obligation to protect the financial interests of the corporation, and thereby the shareholders, may not be compromised by a competing interest in other legitimate corporate purposes, such as fending off a hostile takeover bid. When engaging in defensive maneuvers. . . a director's primary obligation is to ensure the overall fairness, including a fair option price, to the shareholders.").

165. See, e.g., id.

166. Paul L. Regan, What's Left of Unocl?, 26 Del. J. Corp. L. 947, 966 (2001) (discussing the use of defensive measures typically utilized against hostile takeovers available under Delaware corporate law, and explaining that shareholders can misjudge the "intrinsic" value of a firm upon being offered a stock premium by a hostile acquirer).

167. Unocal Corp. v. Mesa Petroleum Co., 493 A.2d 946, 955 (Del. 1985) (“A further aspect is the element of balance. If a defensive measure is to come within the ambit of the business judgment rule, it must be reasonable in relation to the threat posed. This entails an analysis by the directors of the nature of the takeover bid and its effect on the corporate enterprise.").

168. Id.

169. See In re MFW Shareholders Litigation, 67 A.3d 496, 526 (2013) (stating that, "the business judgment rule standard of review applies and precludes judicial second-guessing so long as the board's decision can be attributed to any rational business purpose") (alteration in original).

170. Revlon, 506 A.2d. 173, 185 (ruling that a company must effectuate a merger that maximizes shareholder value when it becomes apparent that a tender offer meets a level exceeding the Unocal standard).

171. See Jens Dammann, The Mandatory Law Puzzle: Redefining American Exceptionalism in Corporate Law, 65 Hastings L.J. 441, 450-51 (2014).

172. See Silverman, supra note 105. 
of actors to whom fiduciary duties are owed provides directors with significant capacity to justify value-stripping actions. After all, an act that harms shareholders can be substantiated if it benefits a stakeholder like the local government. In the Mylan case study, Mylan's directors rebuffed allegations that rejecting Teva's tender offer harmed shareholders, noting that, as a Dutch entity, they owed duties to stakeholders, not just shareholders. ${ }^{173}$

In turn, inverting can change more regulatory frameworks than simply a company's tax rate. While corporate governance is perhaps the bestknown inversion consequence, other lesser-discussed regulatory frameworks include securities and antitrust laws.

\section{B. Securities Law}

Inverting, or otherwise reincorporating abroad, can diminish a company's responsibility to comply with important aspects of U.S. securities laws. The United States has established two functionally different securities frameworks of varying levels of scrutiny and cost. ${ }^{174}$ American corporations are per se subject to the United States' more onerous securities rubric, ${ }^{175}$ which makes a firm's country of incorporation especially important for whether, and to what extent, it must comply with securities regulations, ${ }^{176}$ including auditing, disclosure, and corporate governance requirements. ${ }^{177}$ But, in order to attract international IPOs and other foreign listings, the United States offers foreign corporations listed on U.S. exchanges a more relaxed securities treatment as a "foreign private issuer" (FPI). ${ }^{178}$

173. See infra Section II (in the Mylan example, directors of a Dutch corporation have fiduciary duties to the company's stakeholders, which is distinct from shareholders).

174. See Amir N. Licht, Cross-Listing and Corporate Governance: Bonding or Avoiding?, 4 CHI. J. INT'L L. 141, 142-43 (2003).

175. Pursuant to Rule 405 of the Securities Act of 1933 and Rule 3b-4(c) of the Securities Exchange Act of 1934, the definition of a foreign private issuer entails "any foreign issuer other than a foreign government except an issuer meeting the following condition .... (i). More than 50 percent of the outstanding voting securities of such issuer are directly or indirectly owned of record by residents of the United States; and (ii). Any of the following: (A) The majority of the executive officers or directors are United States citizens or residents; (B) More than 50 percent of the assets of the issuer are located in the United States; or (C) The business of the issuer is administered principally in the United States." 17 C.F.R. § 230.405 (2016); see also Barbara Black, Introduction: The Globalization of Securities Regulation- -Competition or Coordination?, 79 U. CIN. L. REv. 461, 461-62 (2010); see also Christopher Hung Nie Woo, United States Securities Regulation and Foreign Private Issuers: Lessons From the Sarbanes-Oxley Act, 48 Am. Bus. L.J. 119, 151-53 (2011); Soo-Jeong Shin, The Effect of the Sarbanes-Oxley Act of 2002 on Foreign Issuers Listed on the U.S. Capital Markets, 3 N.Y.U. J.L. \& Bus. 701, 701-02 (2007).

176. Natalya Shnitser, A Free Pass for Foreign Firms? An Assessment of SEC and Private Enforcement Against Foreign Private Issuers, 119 Yale L.J. 1638, 1652 (2010) ("The United States effectively has two securities regulation regimes: one for domestic issuers and another for foreign issuers. The latter 'cuts corners' on key issues of corporate governance.").

177. Id. at 1652-53.

178. See generally Steven M. Davidoff Solomon, Regulating Listings in a Global Market, 86 N.C. L. REv. 89, 130 (2007); see also Brummer, supra note152, at 1438 ("[S]tock exchanges are increasingly poised to operate as sellers of both domestic and foreign law."); 
If a U.S. company endeavors to become an FPI, it must reincorporate abroad, perhaps using the inversion process to execute the transaction. ${ }^{179}$ However, the migrating company would still be considered a U.S. corporation for the sake of securities laws, unless non-U.S. residents hold over $50 \%$ of its outstanding voting shares. ${ }^{180}$ If that condition is met, then (1) a majority of the company's executive officers or directors must be foreign citizens, (2) more than $50 \%$ of the firm's assets must be located abroad, and (3) the majority of the corporation's business must be conducted abroad. ${ }^{181}$ While these are typically difficult thresholds for small U.S.based companies to meet, multinational entities generally have a greater capacity to structure their corporate affairs to become an FPI.

After achieving FPI status, a newly minted foreign corporation may avoid filing quarterly reports ${ }^{182}$ and other burdensome disclosure statements. ${ }^{183}$ Since U.S. securities laws also relax corporate governance standards, ${ }^{184}$ commentators have warned that FPIs are likely to generate significant conflicts of interest. ${ }^{185}$ The SEC reduced disclosure obligations of FPIs even further in 2008; FPIs co-issuing securities on foreign exchanges are now only required to disclose primary firm documents translated into English. ${ }^{186}$ The Sarbanes-Oxley Act also permits FPIs to use their home country's accounting methods, as opposed to the typically more rigorous U.S. Generally Accepted Accounting Principles (GAAP). ${ }^{187}$ The result is an attractive securities framework for foreign

Woo, supra note 76, at 152 ("[S]tudies suggest that the costs imposed by SOX are not that significant for foreign private issuers accessing the U.S. market.").

179. 26 U.S.C. $\$ 7874(a)(1)$ (2012) (defining "expatriated," and referring to these companies as such).

180. Cf. 17 C.F.R. $§ 240.3 b-4(c)(2016)$.

181. Cf. id.

182. See, e.g., Shnitser, supra note 176, at 1653 ("Foreign issuers are also exempt from several duties with regard to proxy statements under section 14 of the Exchange Act and short sales and short-swing profits by corporate insiders under section 16."); Licht, supra note 174 , at 152 ("Form $20-\mathrm{F}$ requires foreign issuers to disclose the names of persons known to own more than 10 percent of the issuer's voting securities. Foreign issuers are only required to disclose the total amount of voting securities owned by the officers and directors as a group, without naming them. In contrast, the threshold for US issuers is 5 percent, and issuers must disclose individual holdings of their officers and directors.").

183. Kenneth B. Davis, Jr., The SEC and Foreign Companies-A Balance of Competing Interests, 71 U. PitT. L. Rev. 457, 471 (2010).

184. Shnitser, supra note 176 , at 1653.

185. See Licht, supra note 174, at 152 ("The biggest gap, perhaps, concerns the thorniest issue: disclosure of conflicts of interest. Form 20 -F permits foreign private issuers to disclose aggregate remuneration and aggregate options to purchase securities, unless the issuer already discloses data for individually named directors and officers. Foreign issuers are further exempted from disclosing data concerning material transactions with officers, directors, and control persons, unless the issuer already makes such disclosures. According to Loss and Seligman's authoritative treatise, "[t]hese requirements significantly compromise the more demanding conflict of interest requirements found in Items 402 to 404 of Regulations S-K.") (citing Louis Loss \& Joel Seligman, 2 Securities Regulations 769 (3d ed. 1989)).

186. See 17 C.F.R. $§ 240.12$ g3-2(b) (effective Oct. 10, 2008); Shnitser, supra note 176, at 1652.

187. Black, supra note 176, at 461-62; Yuliya Guseva, Cross-Listings and the New World of International Capital: Another Look at the Efficiency and Extraterritoriality of Securities 
entities.

Importantly, becoming an FPI through the inversion process is more likely to benefit a corporation's management at the expense of shareholders. Consider that securities regulations are thought to safeguard individual investors as opposed to companies and management. ${ }^{188}$ For instance, securities laws establish elevated corporate governance standards and therefore create a level of director accountability. ${ }^{189}$ Likewise, disclosure duties disseminate company information that investors would not otherwise be able to obtain. ${ }^{190}$ Thus, shareholders and directors are likely to disagree about the optimal strength of securities laws because more relaxed regulations generally favor management who tend to benefit from less burdensome compliance duties and limited exposure to litigation.

\section{Mergers and Antitrust}

The inversion process can also create important regulatory advantages on the international merger market, as evidenced by the number of inverted firms that recently have acquired other international corporations. ${ }^{191}$ While most reports have focused on how inverted firms use their lower tax rates to create synergies with foreign merger targets, ${ }^{192}$ seldom is it discussed that inverting can diminish antitrust regulations, making mergers easier - or at least less costly - to accomplish. ${ }^{193}$ From an American corporation's perspective, the regulatory process governing prospective mergers and acquisitions is overly burdensome. ${ }^{194}$ The Hart-ScottRodino Act (HSR Act) requires mergers involving a U.S. corporation and at least one dominant market actor to receive antitrust

Law, 44 GEO. J. INT'L L. 411, 452-53 (2013) (“[N]umerous concessions were made to FPI with respect to compliance with the Sarbanes-Oxley Act of 2002. The SEC, inter alia, grant exemptions from Rule 10A-3 to foreign issuers permitting representatives of governments or specific employees to serve on audit committees and recognizes certain alternative auditing arrangements. Overall, the SEC regulations take into account local variations and functional substitutes existing in foreign jurisdictions with respect to auditing committees, independence of auditors, variations in corporate governance structures . ...").

188. 17 C.F.R. $§ 240.3 b-4(d)$ (2016) ("Notwithstanding paragraph (c) of this section, in the case of a new registrant with the Commission, the determination of whether an issuer is a foreign private issuer will be made as of a date within 30 days prior to the issuer's filing of an initial registration statement under either the Act or the Securities Act of 1933.").

189. See Merritt B. Fox, Retaining Mandatory Securities Disclosure: Why Issuer Choice Is Not Investor Empowerment, 85 VA. L. Rev. 1335, 1393 (1999).

190. Id. at 1338 (explaining that "there is a socially optimal level of disclosure. More information about the issuer and the resulting increase in its share price accuracy produces social benefits in the form of improved selection of new investment projects, improved managerial performance, and reduced investor risk.").

191. See David Crow et al., Tax inversion curb turns tables on US, Fin. Times (Mar. 15, 2015, 10:36 PM), http://www.ft.com/intl/cms/s/0/e1ba6eb0-ca5c-11e4-b8ff00144feab7de.html\#axzz3jf0OegrJ.

192. See id.

193. See Andrew G. Howell, Why Premerger Review Needed Reform-And Still Does, 43 WM. \& MARY L. REv. 1703, 1726-27 (2002) (discussing the costs of antitrust preclearance borne to both society and to individual companies).

194. See, e.g., Stephen Paul Paschall, Antitrust and Hospital Mergers:A Law and Economics Rationale for Exemption, 30 DuQ. L. REv. 61, 65-66 (1991) (describing the antitrust costs in hospital mergers). 
preclearance. ${ }^{195}$ When the proposed merger is between a U.S. corporation possessing more than $\$ 50$ million in assets, the preclearance process becomes especially long and costly. ${ }^{196}$ During that time, the Federal Trade Commission must review whether the proposed acquisition is likely to harm competition; if it does, the merger is blocked. ${ }^{197}$ In light of the cost and uncertainty in the HSR Act, some proposed business combinations are abandoned before serious discussions may begin. ${ }^{198}$

However, foreign corporations enjoy antitrust exceptions, which makes acquisitions easier and cheaper. If a foreign corporation proposes acquiring a foreign entity, it entirely avoids the preclearance requirements unless either (1) the target company owns more than $\$ 50$ million worth of assets in the United States or (2) the aggregate sales, or controlled assets, of both companies is more than $\$ 110$ million. ${ }^{199}$ In turn, the process of inverting can eliminate costly merger regulations when the foreign target company has a limited U.S. presence.

\section{Regulatory Frameworks and Investors}

Although tax benefits are assuredly inverting's primary regulatory advantage, anecdotal evidence suggests that securities, antitrust, and corporate governance considerations also provide incentives to invert. But this raises a significant question. As discussed, because corporate regulations provide shareholders, who have minimal managerial rights, with the means to seek information and protect ownership interests, the inversion process potentially harms shareholders. So why do shareholders authorize corporate inversions? Likewise, why would investors purchase a company's stock that used the inversion process to dismantle shareholder

195. The Hart-Scott-Rodino Antitrust Improvements Act of 1976, Pub. L. No. 94-435, 90 Stat. 1383 (1976). See, e.g., Brown Shoe Co. v. U.S., 370 U.S. 294, 312-13 (1962) (explaining that the Clayton Act, 15 U.S.C.A $\S 18$, "prohibit[s] the acquisition by one corporation of the stock of another corporation when such acquisition would result in a substantial lessening of competition between the acquiring and the acquired companies, or tend to create a monopoly in any line of commerce").

196. 15 U.S.C. § 18a (2012).

197. Matthew S. Bailey, The Hart-Scott-Rodino Act: Needing A Second Opinion About Second Requests, 67 OHIо ST. L.J. 433, 455 (2006) ("On average, compliance with Second Requests costs merger parties $\$ 5$ million; however, it is not uncommon for complex transactions to result in compliance costs upwards of \$20 million. For example, the Exxon-Mobil merger reportedly cost one of the parties more than $\$ 30$ million to comply with the agency's Second Request."); see also Daniel E. Lazaroff, Entry Barriers and Contemporary Antitrust Legislation, 7 U.C. DAvis Bus. L.J. 1, Part III (2006) (explaining the guidelines uses to assess proposed mergers).

198. Paschall, supra note 194, at 65 ("The prospect of antitrust litigation increases the costs and reduces the likelihood of mergers.").

199. 16 C.F.R. $\$ 802.51(b)(1)$ (2016) (In greater detail, the statutory exemption to the HSR Act's preclearance is met if the foreign acquirer: "holds assets located in the United States ... having an aggregate total value of over $\$ 50$ million (as adjusted); or made aggregate sales in or into the United States of over $\$ 50$ million (as adjusted) in its most recent fiscal year,"); 16 C.F.R. § 802.51(c)(2)-(3) ("The aggregate sales of the acquiring and acquired persons in or into the United States are less than $\$ 110$ million (as adjusted) in their respective most recent fiscal years; [and] [t]he aggregate total assets of the acquiring and acquired persons located in the United States . . . are less than $\$ 110$ million”). 
protections? Are individuals acting irrationally when they support these companies or could there be a more logical reason? The following Section empirically tests these questions.

\section{EMPIRICAL ANALYSIS}

The following analysis examines the inversion puzzle by empirically investigating how individuals perceive and invest in companies based upon the regulatory regimes they have adopted and/or avoided. The following hypotheses are tested using two different statistical treatments. The first hypothesis from behavioral economics suggests that investors are hardwired to act irrationally. ${ }^{200}$ In the inversion context, shareholders and investors should logically prefer companies operating under strong legal frameworks, yet anecdotal evidence suggests that individuals ignore corporate law's value and the manner in which it protects shareholder and investor interests. ${ }^{201}$ In Mylan, the company's shareholders overwhelmingly approved Mylan's inversion, which provided Mylan's directors with the means to strip shareholders of critical shareholder protections found under U.S. law. ${ }^{202}$ Considering the foreseeability of this result, and the ensuing destruction of shareholder value, the behavioral economics hypothesis follows that individuals and shareholders irrationally ignore the value of corporate laws when confronted with proposed inversions.

The competing hypothesis asserts that shareholders invest thoughtfully and wisely. ${ }^{203}$ Because inversions are quite complex, it is easy to assume that firms invert for the sake of dismantling shareholder protectionssome may. But many corporations invert in jurisdictions with strong corporate governance, such as Ireland, while others, despite the possibility of becoming an FPI, choose to comply with the more stringent set of U.S. securities regulations. ${ }^{204}$ Considering this narrative, investors may actually comprehend the sophisticated landscape of international transactional law and invest accordingly.

Empirically, these hypotheses are testable. Since firm value is largely determined by the rate in which individuals invest; companies operating under strong regulatory regimes should be valued more than companies that dodge meaningful regulations. ${ }^{205}$ But if investors are indifferent to the law, firm value should turn out to be statistically unrelated to vari-

200. See supra Section III (explaining behavioral economics' application to investing).

201. Id.

202. Id.

203. Id. (explaining the efficient markets hypothesis).

204. See Soyoung Kim \& Olivia Oran, INSIGHT-Irish, Dutch, UK law firms in tax inversion beauty contest in U.S., REUTERS (July 24, 2014), http://www.reuters.com/article/ deals-taxinversions-lawfirms-idUSL2N0PK1L820140724.

205. See Robert Daines, Does Delaware law improve firm value?, 62 J. Fin. Econ. 525, 529 (2001) (explaining the logic that "[i]f investors regularly pay more for assets governed by Delaware law, Delaware firms will be worth more. Similarly, if investors discount the price paid for assets governed by Delaware law, Delaware firms should be worth less.”). 
ables representing various regulatory controls. ${ }^{206}$

\section{A. Research Design}

The following analysis empirically examines the value of the regulatory choices made by publicly traded companies listed on U.S. stock exchanges, using both an ordinary least squares (OLS) regression and probit analysis. The study's unit of analysis is company-year, spanning from 1995 to 2015. Thus, a company has an entry for each year it was publicly traded. This range was chosen because the modern corporate inversion trend began, for the most part, in the mid-1990s. ${ }^{207}$ The dataset, including all companies and most variables, was generated using Compustat. ${ }^{208}$

In the first model-the OLS regression-the dependent variable is Firm Value. ${ }^{209}$ Older works approximated firm value using a company's stock price, but this method has fallen out of favor. ${ }^{210}$ The modern approach, as used in this Article, calculates a company's Tobin's Q. Tobin's $\mathrm{Q}$ is defined as the ratio between a company's market value of assets to its book value of assets. ${ }^{211}$ The formula used to calculate Tobin's Q was provided by an article authored by Ahn and Shrestha. ${ }^{212}$ Again, this Article follows other studies and uses the natural logarithm of Tobin's Q.213

The independent variables (i.e., the variable) that the research was primarily interested in investigating included whether a company had undergone an Inversion and thus, reincorporated abroad with the intent of becoming taxable as a foreign entity. The companies identified as having inverted are those found on the list provided by the Congressional $\mathrm{Re}$ -

206. See id.

207. Hwang, supra note 36, at 824-26 (The second generation of inversions-the first generation after the first anti-inversion laws were passed-started around the Helen of Troy inversion in 1994.).

208. Compustat is the commonly used, industry standard database-compiled by Dow Jones \& Company and offered by the University of Pennsylvania's Wharton School of Business-offering a tremendous sum of information regarding accounting information of publicly trade corporations. Michael Bradley \& Michael Rosenzweig, The Untenable Case for Chapter 11, 101 YALE L.J. 1043, 1063 n.58 (1992).

209. See Table 1 infra Appendix.

210. See Daines, supra note 205, at 528 .

211. Daines, supra note 205, at 530 ("Tobin's Q estimates the firm's market value divided by its replacement cost. This ratio represents a firm's investment or growth opportunities, including those added by management and corporate law rules.").

212. Seoungpil Ahn \& Keshab Shrestha, The Differential Effects of Classified Boards on Firm Value, 37 J. BANKING \& Fin. 3993, 4011 (2013) (explaining, using Compustat, that Tobin's Q can be found by calculating "the ratio of the market value of assets to Compustat item 6 , assets. The market value of assets is obtained as item 6 , assets, - item 60 , common equity, + market value of equity (item 199, price-close, $\mathrm{x}$ item 54, shares outstanding.").

213. See, e.g., George Allayannis et al., The use of foreign currency derivatives, corporate governance, and firm value around the world, 87 J. INT'L ECON. 65, 68 (2012) (using the natural $\log$ of Tobin's Q.). 
search Service. ${ }^{214}$ Inversion was coded using a "dummy" variable, meaning that a coding of a " 1 " represents that the company inverted, while " 0 " means that it did not invert. For example, if a company inverted in the year 2000, Inversion was coded as a 1 for each company-year beginning with, and following, the year 2000. All prior years received a "0." This variable was expected to be statistically significant-meaning that inversions were not randomly associated with firm value, but instead actually influenced firm value. If inverting promoted firm value, then the Inversion coefficient should have been positive and significant, but if inversions harmed firm value, then the Inversion coefficient would be negative and significant. ${ }^{215}$

Next, inverted companies are thought to incorporate in jurisdictions with poor corporate governance regimes. ${ }^{216}$ Since prior research has shown that ineffective corporate governance laws detract from firm value, ${ }^{217}$ the second independent variable represents the Corporate Governance rating in the country of incorporation. The variable was drawn from Governance Metrics International (GMI), which provides national corporate governance scores. ${ }^{218}$ GMI determined each country's score based upon their tolerance of, for example, non-independent boards of directors. The scores ranged from a high of 7.60 to a low of 2.13. Most likely, as indicated by prior works, corporate governance will have a positive relationship with firm value, with stronger corporate governance structures enhancing firm value. ${ }^{219}$

The third independent variable indicates whether a company complied with the onerous U.S. securities regime or the less burdensome framework as an FPI. Recall that U.S. corporations inherently receive the more taxing security treatment. ${ }^{220}$ However, foreign companies may potentially become an FPI using the inversion process as a means to avoid burdensome auditing, corporate governance, and disclosure requirements. 221

214. A Spike in Corporate Inversions, Democrats Ways AND Means, http://democrats.waysandmeans.house.gov/sites/democrats.waysandmeans.house.gov/files/ A_Spike_in_Corporate_Inversions.pdf (last visited Jan. 13, 2016).

215. See Daines, supra note 206 at 525-26; see, e.g., Michael Hiltzik, Pfizer's creative merger plan revives concerns about tax-avoiding 'inversions,' L. A. TIMES (Nov. 16, 2015), http://www.latimes.com/business/hiltzik/la-fi-mh-pfizer-s-creative-merger-20151116-column.html (discussing the negative backlash following the Pfizer inversion).

216. Kim \& Oran, supra note 204 (noting that directors prefer to invest in the Netherlands due to the country's pro-management corporate governance rules).

217. See, e.g., Daines, supra note 205, at 547-49 (finding that Delaware's strong governance laws improves firm value).

218. MSCI, https://www.msci.com/esg-integration.

219. Paul A. Gompers et al., Corporate Governance and Equity Prices, 118 QuARTERLY J. ECON. 107, 125-28 (2003) (finding stronger corporate governance laws promoting shareholder rights promotes firm value).

220. See supra Section IV.B (discussing how place of incorporation affects a firm's relationship with U.S. securities laws).

221. Larry A. Cerutti \& Jason Lee, Corporate Inversions: Considerations Other Than Tax Benefits, BNA's Corporate Counsel Weekly (Sep. 24, 2014) (noting that inverted firms can potentially qualify as a foreign private issuer). 
This variable, referred to as FPI, is captured by a dummy score: 1 equaling foreign private issuer, while 0 entails any other arrangement.

But perhaps there is a difference between being an actual foreign FPI or an American-headquartered FPI. Indeed, it should be of little surprise that a foreign headquartered/incorporated firm listed on a U.S. exchange would take advantage of the many FPI exceptions because after all, current law incentivizes this outcome. ${ }^{222}$ Investors might also be more skeptical of a U.S.-headquartered firm, which has reorganized its corporate structure to become an FPI. This type of strategy may be viewed as a surreptitiously naked regulatory stripping action. Considering this possibility, the variable USA FPI was added. It is represented by a "1" if a firm is domestically headquartered yet organized abroad as an FPI. All other observations receive a " 0 ." USA FPI will potentially demonstrate that such firms are received more harshly than truly foreign FPIs.

Another important variable is a company's Corporate Tax Rate. ${ }^{223}$ Most evidence suggests that tax rates are important, especially in light of the resources spent by companies to invert. ${ }^{224}$ While there is an Inversion variable, Inversion only captures a small collection of tax-motivated companies. After all, many wholly foreign firms listed on U.S. exchanges already enjoy their country's more favorable corporate tax rate. A variable was also included to reflect the actual tax rate of the country in which a company was incorporated. For instance, if a company incorporated in the United States during a certain year, the observation for Tax Rate would be coded as " 35 " for the $35 \%$ in taxes that most U.S. corporations pay annually. The inclusion of the Tax Rate provides for more accuracy than a dummy variable for inversions. But it should be noted that despite the Tax Rate's inclusion, a specific variable for Inversion is also still necessary. This is due to the fact that inverted companies may receive particularly harsh treatment by politicians and commentators and must expend significant company resources to invert. ${ }^{225}$ So although Inversion and Tax Rate capture similar effects, they are also substantially different, but both are critically important.

This study also controlled for a statistical quirk with powerful effects on analysis. In certain circumstances, independent variables have an interactive effect when ideally they would be completely independent of each

222. See Dammann, supra note 171 , at $450-51$ (discussing the defensive measures against hostile takeovers available under foreign law).

223. The variable for Corporate Tax Rate was drawn from information supplied by KPMG. Corporate Tax Rates Table, KPMG, https://home.kpmg.com/xx/en/home/services/ tax/tax-tools-and-resources/tax-rates-online/corporate-tax-rates-table.html (last visited Jan. 13,2016 ) (The data goes back only to 2006 . Because corporate tax rates are generally static, the 2006 value was imputed onto the prior years.).

224. See Coyle, supra note 158, at 1942 (mentioning that most commentators intuitively believe that tax rates attract company relocation decisions, though some studies cast doubt on how strong of an effect taxes actually have).

225. See Fleisher, supra note 39 (discussing the government costs on a transaction); Kim \& Oran, supra note 205 (suggesting that law firms who structure these inversion transactions receive large fees for their services). 
other. Here, one of the potentially problematic relationships was between inversions and corporate governance. Recall that inversions require a company to reincorporate abroad, where it becomes amenable to that country's corporate governance laws. But it is likely that investors have a special reaction when a company invests in a country with porous corporate governance laws, as opposed to the company initially being headquartered and incorporated in a weak corporate governance country. Or, likewise, investors may react particularly favorably to a company that inverts in a place with strong corporate governance and low taxes. This reaction may be greater than either of those two elements independently. This methodological quirk was mitigated using an interactive variable, which entailed multiplying the Inversion variable with the Corporate Governance variable. The interactive variable's effect helps both Corporate Governance and Inversion display their true effect, while also indicating the statistical significance of the possible interaction. Similarly, there was an expected interaction variable for corporate tax rate and corporate governance.

Spurious correlations cause another problem, which happen when two variables appear related when, in fact, they are not. Spurious relationships are common when research fails to account for other variables that are actually driving the relationship. ${ }^{226}$ To avoid this error, an analysis should account for certain variables that prior research has determined to affect firm value. If the key independent variables prove to be statistically significant, even when factoring in the control variables, then there can be a high level of confidence with respect to the results. The first control variable is a company's Size, which was measured by the log of a company's total assets. Other salient control variables included a company's Free Cash Flow and Return on Assets. A company's Capital Expenditures was measured by the ratio of a company's capital expenditures to assets. Similarly, a variable is included for a company's Research and Development, which was also taken as a ratio to its assets.

The second model is a probit analysis using many of the same variables. ${ }^{227}$ A probit model is appropriate when the dependent variable is, like Inversion, binary. By making Inversion the dependent variable, the analysis sought to determine which countries firms actually tend to invest in. Although the first model endeavors to explain how the regulatory choices available through different inversion homes affects firm value, it was also imperative to determine whether the inversion process is actually structured, in general, to help or harm shareholders. By using a dependent variable of Inversion, it is possible to determine where exactly firms migrate. For instance, if Corporate Governance is positive and significant, this result would indicate that inverted firms are more likely to

226. See, e.g., Alissa Pollitz Worden et al., A Patchwork of Policies: Justice, Due Process, and Public Defense Across American States, 74 Alb. L. Rev. 1423, 1436-37 (2011) (ameliorating a spurious relationship using control variables).

227. See Table 2, infra Appendix. 
adopt stronger corporate governance schemes upon inverting. Likewise almost assuredly Corporate Tax Rate will be negative because it is nearly impossible for an inverted firm to relocate to a jurisdiction with a higher corporate tax rate than the United States.

\section{B. Results}

The results of the models suggest a shocking result: investors care deeply about the law. In fact, investors seem to take a rather nuanced approach to investing. Nearly all of the study's variables proved to be statistically significant at greater than $.001 \%$ level, meaning that the odds a variable is causally related to Firm Value is greater than $99.9 \%$. We can infer that, instead of being merely correlated, the study's independent variables are very likely causally related to firm value.

In the OLS analysis, ${ }^{228}$ the first important result concerned the noninteractive Inversion variable, which was statistically significant in the second OLS model but insignificant in the first. Inversion's insignificance may at first blush seem odd, but it makes perfect sense considering the other control variable, Corporate Tax Rate. Indeed, the major advantage that investors gain from inverting is a reduced corporate tax rate. ${ }^{229} \mathrm{Be}-$ cause this study controls for Corporate Tax Rate, the tax benefits of Inversion are captured by another, more nuanced variable, cannibalizing Inversion's demonstrated effect. Notice, however, that in Table 1's second model, which excludes Corporate Tax Rate, Inversion is positive and negative. So by controlling for a company's tax rate, it seems that investors are generally interested in inversions to the degree that the transaction modifies a company's tax rate, but an inversion's independent effect is less significant. Thus, while investors prefer lower corporate taxes, they do not necessarily care about the type of transactions bringing about this result. And since the first model already controls for Corporate Tax Rate, Inversion primarily captures only the stigma and costs associated with inverting, which were negligible.

However, there is one salient caveat; the interactive variable Inversion*Corporate Governance was positive and significant. This suggests that there is a special positive relationship between inversions and corporate governance. When a company inverts into a country with stronger corporate governance laws, firm value increased. If investors were unable to distinguish between a new inversion home's corporate governance structures, this variable would have been statistically insignificant. So while investors appear to generally care little about the actual inversion transaction beyond its tax savings, investors do reward inverting firms when they strengthen the regulatory systems under which they operate, while simultaneously lowering taxes. This result suggests that investors

228. See Table 1, infra Appendix.

229. See Kim \& Oran, supra note 204. 
take a rather nuanced stance with respect to, not just whether a company inverts, but how it inverts.

As expected, Corporate Governance was significant and positively related to Firm Value. Unsurprisingly, this finding indicates that investors care about the corporate governance structures under which companies operate. The stronger the laws, and thus investor protections, the more likely individuals will invest in that company, which bolsters firm value. Again, this result is not revolutionary but rather conforms to most prior research. 230

Likewise, note that the interaction between corporate governance and corporate tax (Corporate Governance*Tax) is highly significant and negative. It makes sense that, all things being equal, investors favor companies paying fewer taxes (and thus the negative coefficient) in a stronger corporate governance regime. So in the aggregate, it seems that companies that pay lower taxes, while providing strong shareholder protections, are valued higher than other companies.

The aforementioned results have been primarily concerned with an inversion's consequences on tax and corporate governance, but other salient regulatory effects are implicated as well. As discussed earlier, foreign incorporated companies are often eligible for the less burdensome set of U.S. securities laws, though a company gaining FPI status has a greater potential of harming shareholders. ${ }^{231}$ Firm Value was typically bolstered by a company's status as an FPI unless the company was actually headquartered in the United States. This aligns with expectations. Foreign headquartered/incorporated companies should naturally pursue FPI status since this arrangement is the natural incentive structure offered by U.S. securities policy. And in accordance with the literature, foreign firms that "bind" themselves to the strength and reputation of American securities laws receive added value. ${ }^{232}$ American corporations, however, appear more unscrupulous when they migrate countries by potentially using an inversion with the hopes of evading certain U.S. securities laws. In other words, while the lesser U.S. securities laws improve a wholly foreign firm's value, U.S.-based companies are penalized by investors for avoiding stronger U.S. securities laws. Indeed, the logic of this result further indicates that investors and shareholders have a strong understanding of the relationship between companies and regulatory systems, and thus likely invest in inverted firms accordingly.

230. Gompers et. al., supra note 219 , at 125 .

231. See Shnitser, supra note 177 at 1652-54.

232. John C. Coffee, Jr., The Future as History: The Prospects for Global Convergence in Corporate Governance and Its Implications, 93 Nw. U. L. REv. 641, 674 (1999) (describing the "bonding" phenomenon in which a firm incorporated in a country with weaker securities laws goes public in the United States in order to signal to investors the company's dedication to transparency by assuming the United States' more taxing securities laws); see also Craig Doidge et al.,, Why are foreign firms listed in the U.S. worth more?, 71 J. FIN. ECON. 205, 207 (2004) ("We argue that cross-listing helps controlling shareholders commit to limit their expropriation from minority shareholders and increases the ability of firms to take advantage of growth opportunities."). 
The research also controlled for whether a firm was both Foreign incorporated and headquartered. Potentially legitimate or even xenophobic concerns may cause investors to avoid or reluctantly invest in non-American companies. Or perhaps U.S. investors wish to support American companies in order to promote American employees, products, and research and development. The Foreign variable did, in fact, prove significant and negative, meaning that, all things considered, investors and shareholders prefer American-based corporations traded on a U.S. stock exchange.

Adding to the strength of the OLS regression's results is that all of the control variables-i.e., variables which the literature has previously established as being meaningful related to firm value-were significant. Naturally companies with strong Research and Development aided Firm Value. Likewise, Free Cash Flow, Capital Expenditures, and Leverage bolstered a company's value, while Size and Return on Assets detracted.

These findings are reinforced by the probit analysis where Inversion is the dependent variable. ${ }^{233}$ Here, Corporate Tax Rate was significant and negative, meaning that inverted firms flock to countries with lower tax rates; but considering that the United States' standing as having the highest corporate tax rate, an opposite finding would have likely been impossible. Importantly, Corporate Governance was positive and significant, indicating that inverted firms are more likely to relocate to countries with strong corporate governance structures. This is a particularly insightful finding because it refutes the prior assumption that management-friendly governance structures attract more inversions. But with that said, although the analysis suggests that a stronger corporate governance structure improves the chances of inverting, it does not indicate whether a company's corporate governance regime is weaker than its former U.S. structure. Inverted companies are also less likely to become a Foreign Private Issuer, indicating that inverted firms are generally restrained from unraveling regulatory protections during and after the inversion process. So, in conclusion, inverted firms are likely to migrate to countries with strong rules of law, despite the thought that companies would likely try to engage in regulatory-stripping transactions.

\section{IMPLICATIONS, POLICIES, AND SUGGESTIONS}

Section V's empirical analysis has important implications for corporate law's development. Importantly, the findings are not just theoretical, they underlie several policy suggestions. The first finding concerns the Article's primary inquiry: are investors and shareholders acting rationally when they approve, or consent to, corporate inversions?

\section{A. InVEStor Rationality?}

The results help to advance the debate between traditional and behavioral economics literature by demonstrating how these two frameworks

233. See Table 2 infra Appendix. 
should optimally coexist. The manner in which individuals perceive and respond to corporate and business laws lies at the center of the inversion puzzle. Although the above statistical treatment provides important insights, one's conclusions must be tempered. On the surface, the study suggests that investors are quite rational, considering that firm value tends to drop when a company engages in regulatory-stripping transactions, while rising when improving shareholder rights and protections. Although the inclination is that most individuals lack time and sophistication, which prevents them from engaging in exhaustive research, this ignores the role of institutional investors who exercise savvy and expend resources when navigating the market. ${ }^{234}$ Because most retail investors piggyback onto institutional investors, even by simply relying upon publicly available stock prices, investor behavior appears to be, economically speaking, rational. 235

Applying these results to inversions, individuals likely support inverted companies because of the heterogeneity of inversion transactions. Recall that inversions have many moving parts, all of which affect the wisdom of inverting from both a shareholder and director standpoint. It thus makes plenty of sense why Ireland is a common inversion destination; not only does Ireland offer a low corporate tax rate, its corporate government structure protects shareholders. ${ }^{236}$ While the Mylan case study and similar examples may cast doubt on whether investors understand the regulatory dangers of inverting, shareholders tend to understand the importance of tax, corporate governance, securities, and antitrust lawsand invest accordingly.

But a bit of a puzzle remains. If investors generally act rationally, why, on certain occasions, do investors still consent to head-scratching transactions? Recall the research found in Section V, why did Mylan's shareholders overwhelmingly approve the company's Dutch inversion in light of the dangers found in Dutch corporate law? Also, for example, why did investors rush to invest in the Chinese company Alibaba, which recently executed a series of transactions intended to avoid meaningful regulations?237 Indeed, when Alibaba sought to go public, the company created a Cayman Islands shell company (the Shell), contracted the Shell to receive Alibaba's profits, and then placed the Shell's securities on the New York Stock Exchange. ${ }^{238}$ If either Alibaba or the Shell were to breach

234. See Cartwright, supra note 118, at 1099.

235. Id. (mentioning that retail investors tend to invest through institutional investors due to their resources and sophistication).

236. Ireland not only offers one of the lowest corporate governance rates of any developed countries, Ireland also scored the highest on GMI Rating's corporate governance scale. See Kim \& Oran, supra note 204.

237. Carlos Tejada, U.S. Report Casts Doubt on Legal Structure of Alibaba, Other Chinese Firms, Wall ST. J. (Jun. 20, 2014, 4:49 PM), http://www.wsj.com/articles/u-s-reportcasts-doubt-on-chinese-e-commerce-legal-structure-1403257238.

238. David Riedel, Four Reasons to Avoid the Alibaba IPO, Forbes.com (Sept. 15, 2014) http://www.forbes.com/sites/investor/2014/09/15/four-reasons-to-avoid-the-alibabaipo/; Charles Clover, Alibaba IPO shows foreign investors able to skirt restrictions, FIN. Times (May 7, 2014), http://www.ft.com/intl/cms/s/0/7a8c4816-d5df-11e3-a017- 
this contract, Chinese and Cayman Islands laws would likely not provide shareholders with a remedy. ${ }^{239}$ In fact, commentators suggest that Alibaba selected the NYSE to take advantage of the exchange's relaxed foreign private issuer rules. ${ }^{240}$ Indeed both the London and Hong Kong exchanges would have forbidden the manner in which Alibaba's majority voting power is vested in a small group of minority shareholders. ${ }^{241} \mathrm{De}$ spite these warning signs, Alibaba recorded the most lucrative IPO in history, raising more capital than any prior offering. ${ }^{242}$ So how can we harmonize this Article's results that emphasize investor rationality with anecdotal evidence pointing to the opposite conclusion?

Inversions seem to put traditional economics and behavioral economics in their proper places. First, consider that despite the modern popularity of behavioral economics, actors generally weigh the regulatory costs and benefits of a transaction, resulting in thoughtful decision-making. ${ }^{243}$ This means the deleterious consequences predicted by behavioral economics are not nearly as predominant as they may appear. Although behavioral economics does accurately describe certain pathologically hardwired cognitive problems, these phenomena are likely to exist on the error term. Although traditional economics has superior explanatory power, rationality escapes even the most sophisticated institutional investors on some occasions and for some reason. This leads to self-defeating herd behavior. This is also precisely how traditional and behavioral economics should relate; while traditional economics better explains the majority of market

00144feabdc0.html?siteedition=UK\#axzz3ZkcPMeFL (explaining the "variable interest entity" was created with the purpose of allowing foreigners to own a stake in Chinese internet companies without actually owning a share).

239. See generally Serena Y. Shi, Dragon's House of Cards: Perils of Investing in Variable Interest Entities Domiciled in the People's Republic of China and Listed in the United States, 37 Fordham InT'L L.J. 1265, 1296-1300 (2014); see also Steven Davidoff Solomon, Alibaba Investors Will Buy a Risky Corporate Structure, N.Y. Times (May 6, 2014), http:// dealbook.nytimes.com/2014/05/06/i-p-o-revives-debate-over-a-chinese-structure/?_r=0

(noting that Cayman Islands law requires investors to pursue a remedy under Chinese law. However, investors may be unable to enforce their contractual rights under Chinese law, especially considering that the VIE arrangement may be illegal.).

240. Frequently Asked Questions About Foreign Private Issuers, Morrison \& FoersTER, http://www.mofo.com/generalcontent/aboutus/overview (last visited Apr. 8, 2016) (mentioning some of the disclosure requirements from which foreign private issuers are excluded).

241. Liz Hoffman \& Telis Demos, Easier Rules Lure Foreign Firms to List in U.S., WALL ST. J. (Mar. 21, 2014), http://www.wsj.com/article_email/SB1000142405270230402 6304579449702968537802-1MyQjAxMTA1MDEwMjExNDIyWj?cb=logged

0.8587873768992722 ("Unlike venues in London and Hong Kong, their main rivals in the race for global listings, the New York Stock Exchange and the Nasdaq Stock Market allow corporate insiders who collectively own less than half their company's stock to exercise control through dual-share structures and other means. In addition, many foreign companies are exempted from some of the disclosure requirements imposed on U.S. corporations.").

242. Liyan Chen et al., Alibaba Claims Title for Largest Global IPO Ever with Extra Share Sales, Forbes.com (Sept. 22, 2014) http://www.forbes.com/sites/ryanmac/2014/09/22/ alibaba-claims-title-for-largest-global-ipo-ever-with-extra-share-sales/.

243. See supra Section II. 
events, behavioral economics fills in the gaps. ${ }^{244}$ Behavioral economics is thus not meant to be a stand-alone guiding principal for all economic behavior, but rather, a means to explain anomalous situations where rationality has gone missing. If behavioral economics were able to describe economics and investor behavior as a whole, the market would resemble chaos. Thus, the key is determining when scholars should look to behavioral economics for help.

\section{B. What to Do About Inversions?}

There has been plenty of discussion and hand wringing about proper policy responses to the inversion trend. Inversions ostensibly harm two different spheres of actors: investors and the public at large. With respect to the former actors, corporate and business laws are generally meant to protect individuals, such as shareholders and investors, who may invest or have invested in a company. ${ }^{245}$ However, the research herein, indicates that individuals likely do not need protection-at least from potentially harmful inversions. After all, the companies most likely to invert are large multinational corporations that have a predominant shareholder base of institutional investors. These sophisticated investors spend substantial resources that retail investors typically follow along with, as the expenditures result in thoughtful decision-making. ${ }^{246}$ So in light of the societal and private costs of public regulations, it is likely that investors do not need statutory inversion protections from corporate inversions.

However, the public may be a different story. The harm inverting companies inflict on the United States includes erosion of the tax base and stranding international capital. ${ }^{247}$ But how much momentum the inversion trend is generating may be a bit overstated. Considering the rules limiting an inversion's merger partners and locations, many companies are likely to find inverting less profitable and desirable than commonly thought. ${ }^{248}$ After all, an inversion requires the consent of both directors and shareholders who often have diverging preferences. Because of this collective action problem, the amount of economically feasible inversions that would appeal to both sets of actors is rather slim. This is likely due to the much-publicized size of the Allergan inversion and Mylan's soap opera. Thus, the inversion trend seems more popular than in actuality. So if policymakers endeavor to completely eradicate inversions, the best solutions would entail allowing firms to repatriate foreign held capital without suffering the U.S. corporate tax rate, ${ }^{249}$ or even lowering the

244. Accord John M. Newman, Antitrust in Zero-Price Markets: Foundations, 164 U. PA. L. Rev. 149, 187-88 (2015) (explaining the limitations of behavioral economics in the antitrust context).

245. See Daines, supra note 206 at 526.

246. See Section V's Empirical Analysis.

247. See Hiltzik, supra note 216.

248. See Raice \& Hoffman, supra note 87.

249. Zahrt, supra note 13, at 1612-14. 
corporate tax rate, ${ }^{250}$ but the lost revenue generated by these strategies may outpace what could be saved by tolerating a handful of future inversions.

\section{International Competition for Corporate Laws}

Another area of contribution concerns the international competition for corporate charters. There used to be little question about the corporate laws and regulatory systems with which a company would comply. Traditionally, American companies incorporated in the United States, went public on the New York Stock Exchange, and then paid their taxes to federal and state authorities. ${ }^{251}$ European and other international companies operated similarly by abiding by their home jurisdictions' business laws. ${ }^{252}$ In fact, unlike U.S. companies, European firms traditionally lacked an incorporation choice and thus, were forced to incorporate under their home country's laws. ${ }^{253}$

This landscape radically changed when the European Court overturned the old seat of incorporation rule, which granted European firms the freedom to incorporate in foreign jurisdictions. ${ }^{254}$ Those rulings flooded the international market with European firms searching for places in which to incorporate. A number of countries responded by manipulating and marketing their regulatory statutes in hopes of attracting drifting firms, their business segments, and corporate charters. ${ }^{255}$ Due to this sea of change, modern companies now view regulatory structures as options and simply choose the bodies of law that best fit their needs. ${ }^{256}$ For instance, companies are able to consider a number of countries when making the

250. Id. at $1614-15$.

251. See Chris Brummer, Stock Exchanges and the New Markets for Securities Laws, 75 U. CHI. L. Rev. 1435, 1437 (2008) (noting that traditionally the U.S. federal government and the SEC had a monopoly over American securities offerings).

252. Ehud Kamar, Beyond Competition for Incorporations, 94 GEO. L.J. 1725, 1727 (2006) ("Unlike American states, most members states in the European Union have longfollowed the so-called real-seat rule, which prevents companies operating in these member states from incorporating abroad."); See also Brummer, supra note 152, at 1450-51 (noting that most countries traditionally went public on their local stock exchange in the absence of any global competition for securities offerings).

253. See Kamar, supra note 252, at 1727.

254. See Case C-167/01, Kamer van Koophandel en Fabrieken voor Amsterdam v. Inspire Art Ltd., 2003 E.C.R. I-10155; Case C-208/00, Überseering BV v. Nordic Constr. Co. Baumanagement GmbH (NCC), 2002 E.C.R. I-9919; Case C-212/97, Centros Ltd. v. Erhvervs-og Selskabsstyrelsen, 1999 E.C.R. I-1459; Kane \& Rock, supra note 5, at 1230-31 (mentioning that the European Court of Justice granted European corporations the freedom to incorporate in foreign countries in a series of rulings).

255. See, e.g., Brummer, supra note 152, at 1438 (finding that countries can attract companies using their securities law because "stock exchanges are increasingly poised to operate as sellers of both domestic and foreign law").

256. Fleischer, supra note 39, at 238 (explaining that transactional lawyers often structure deals to exploit the advantages of certain bodies of law over another jurisdiction's laws, creating what is known as "regulatory arbitrage"). See, e.g., Omri Marian, Jurisdiction to Tax Corporations, 54 B.C. L. Rev. 1613, 1614-15 (2013) (noting that tax law is often viewed as a choice: "corporate tax residence is elective. Taxpayers can arrange the tax residence of corporations as they see fit, and avoid taxes."). 
incorporation decision ${ }^{257}$ and when going public; IPO options often include the London and Hong Kong stock exchanges, as well as some developing securities markets. ${ }^{258}$ Even established companies are becoming increasingly likely to switch to the laws of a foreign nation. ${ }^{259}$ For instance, the bank HSBC has openly discussed abandoning London due to the United Kingdom's costly regulatory regimes in favor of Hong Kong's more promising treatment. ${ }^{260}$

Debate exists over whether the enactment and enforcement of business laws to attract international companies actually resembles a race to the top or bottom. ${ }^{261}$ Although both camps agree that the decision of where to incorporate is strategic, the argument centers on whether firms migrate towards national regulatory systems increasing shareholder value-race to the top-or whether companies prefer jurisdictions that protect management - race to the bottom. ${ }^{262}$ According to this camp, evidence supporting the race to the top arguments can be found in the strength of Delaware's corporate regime, which one study found increases firm value. ${ }^{263}$ In other words, jurisdictions can best compete against Delaware's corporate dominance by enacting laws that promote shareholder interests, which in turn have the effect of increasing firm value.

However, race to the bottom advocates note that since the party most often tasked with orchestrating corporate transactions is management, firms are most attracted to countries that shield directors and officers from shareholder lawsuits, hostile takeovers, and other similar actions, even though these policies are likely to harm company value. ${ }^{264}$ Consider the state of Nevada, for example, which has sought to compete against Delaware by eliminating director liability. ${ }^{265}$ Instead of encouraging responsible management, Nevada has determined that the best way to attract firms is to instill decidedly pro-management policies. ${ }^{266}$

While both of these theories appear anecdotally persuasive and internally logical, the above research suggests that the race to the top advocates might be correct. ${ }^{267}$ The statistical study indicates that investors and

257. Kane \& Rock, supra note 5, at 1230-31.

258. See generally Nicholas Calcina Howson \& Vikramaditya S. Khanna, Reverse CrossListings-The Coming Race to List in Emerging Markets and an Enhanced Understanding of Classical Bonding, 47 Cornell INT'L L.J. 607, 624 (2014).

259. See The Rise of Corporate Inversions, KellogG Insight (Apr. 6, 2015), http:// insight.kellogg.northwestern.edu/blogs/entry/the-rise-of-corporate-inversions/.

260. Mike Bird, HSBC should ditch London for Hong Kong is 'logical place' to go, Bus. INSIDER (Apr. 27, 2015), http://www.businessinsider.com/hsbc-should-ditch-london-andhong-kong-is-the-logical-place-to-go-2015-4.

261. See supra notes 31-35 and accompanying text.

262. Id.

263. Daines, supra note 205, at 527-28.

264. See Eric Kades, Freezing the Company Charter, 79 N.C. L. REv. 111, 114-15 (2000).

265. Michal Barzuza, Market Segmentation: The Rise of Nevada as a Liability-Free Jurisdiction, 98 VA. L. REV. 935, 938-45 (explaining how Nevada redrafted its corporate governance laws to immunize directors from even legitimate malfeasance claims).

266. Id.

267. See discussion supra Section V. 
shareholders rationally understand and respond to corporate regulations. Consider the finding that firms pursuing regulatory-stripping transactions quickly lose value, while the corollary increases it. Since shareholders must approve an effective inversion, as well as most other significant corporate structure changes, investors are likely to reject a fundamentally counterproductive transaction. ${ }^{268}$ This contention is backed by commentators who note that most shareholder actions are fronted by savvy institutional investors. ${ }^{269}$ So although management designs corporate transactions, regulatory-stripping efforts are unlikely to be efficacious, since shareholders should likely block them. Because the empirical results indicate that investors and shareholders respond rationally to inversions and other regulatory changing transactions, a country's best strategy to attract corporate charters and business is to enact and promote shareholder friendly, value-adding laws.

\section{CONCLUSION}

Recent popular and scholarly writings have intensely scrutinized the inversion trend. Most of these articles have focused on the desire of companies to erode the U.S. tax base, while a few others have noted their effects on corporate governance schemes. Less noticed is how these transactions affect a few other regulatory frameworks, including securities and antitrust laws. Indeed, the United States is notorious for enforcing particularly burdensome regulatory regimes, adding costs and cumber to the process of running a company. In this light, most accounts suggest that foreign migrations make sense because corporate directors benefit by having to comply with less rigorous regulations.

But it is often lost that corporate migrations are significantly more puzzling when considering the preferences of shareholders. Shareholders should value the law, as expressed through their investing behaviors. Investors and shareholders should thus disfavor inversions and other international transactions that diminish their rights and protections. After all, regulatory frameworks are generally thought to benefit shareholders and investors, which corporate migrations seem to undermine. Considering this framework, shareholders should refuse to consent to corporate migrations and individuals should disfavor investing in inverted companies.

Whether these observed investor behaviors are surprising depends upon the body of literature to which one subscribes. The traditional framework suggests that investors are rational and consider all aspects of a company before investing. Under this framework, corporate migrations appear odd since shareholders should understand and value regulatory frameworks, while acting accordingly. The more popular theory comes from behavioral economics which suggests that people are poor investors.

268. See Talley, supra note 2 , at 1686 .

269. See generally Jennifer O'Hare, Retail Investor Remedies Under Rule 10B-5, 76 U. Cin. L. Rev. 521, 533-35 (2008) (describing the relationship between and investing behaviors of sophisticated institutional investors and retail investors). 
More specifically, psychological limitations hamper the ways in which individuals approach the market, causing investors to overvalue, undervalue, or even ignore certain salient factors. Under this framework, the seemingly irrational support that shareholders have given to inversions is more understandable. A goal of this Article is to compare and test these competing accounts.

The empirical results of this Article suggest that investors do consider the law thoughtfully and rationally. Most regulatory eroding behaviors appear to diminish firm value while strong legal regimes add to a firm's worth. The key to these findings is that the international regulatory environment is quite complex. Investors do enjoy the value gained from a lower tax rate but only as long as the company reincorporates in a jurisdiction with, as an example, a comparably strong corporate governance statute.

However, the research herein does not attempt to answer why Mylan's shareholders, or other similarly situated investors, consented to a specific inversion or other tax-driven migration. In fact, in light of the research, Mylan's inversion is even more perplexing and should serve as a cautionary tale. Shareholders certainly found themselves in a precarious situation where they had few tools available under Dutch law to contest their board's value-reducing actions, especially compared to American law. But this is likely where the strength of behavioral economics lies. While it does not necessarily describe investor behaviors as a whole, it does explain why in certain situations even sophisticated institutional investors seem to make pathologically poor decisions. 
$\begin{array}{ll}\text { SMU LAW REVIEW [Vol. } 69 & \end{array}$

APPENDIX

TABLE 1.

\begin{tabular}{|c|c|c|}
\hline & 1 & 2 \\
\hline \multicolumn{3}{|l|}{ Independent Variables } \\
\hline Inversion & $\begin{array}{l}-.3188437 \\
(.2926558)\end{array}$ & $\begin{array}{l}\mathbf{- . 4 8 6 9 6 4 9} * \\
(.2923579)\end{array}$ \\
\hline Corporate Governance & $\begin{array}{l}\mathbf{. 0 1 0 9 5 9 1} \\
(.0124581)\end{array}$ & $\begin{array}{l}-.1029418 * * * * \\
(.0061237)\end{array}$ \\
\hline Foreign Private Issuer & $\begin{array}{l}. \mathbf{2 2 9 1 3 9 6} \text { **** } \\
(.0135029)\end{array}$ & $\begin{array}{l}\mathbf{2 3 8 3 7} * * * \\
(.0134807)\end{array}$ \\
\hline Corp. Tax Rate & $\begin{array}{l}. \mathbf{0 2 2 3 0 2 7} * * * \\
(.0021247)\end{array}$ & \\
\hline Govern*Taxes & $\begin{array}{l}-.0033021 * * * \\
(.0004395)\end{array}$ & $\begin{array}{l}\mathbf{. 0 0 1 1 2 9 2} * * * * \\
(.0001224)\end{array}$ \\
\hline Inversion $*$ Govern & $\begin{array}{l}\mathbf{1 3 8 4 7 6 6} \text { **** } \\
(.0444519)\end{array}$ & $\begin{array}{l}\mathbf{1 7 6 4 2 5 2} * * * * \\
(.044326)\end{array}$ \\
\hline Size & $\begin{array}{l}\mathbf{- . 1 8 2 9 2 1 9} * * * \\
(.0009405)\end{array}$ & $\begin{array}{l}\mathbf{- . 1 8 2 3 8 2 8} * * * * \\
(.0009396)\end{array}$ \\
\hline Leverage & $\begin{array}{l}.0022971 * * * \\
(.000097)\end{array}$ & $\begin{array}{l}\mathbf{. 0 0 0 0 9 7} * * * \\
(.0000963)\end{array}$ \\
\hline Return on Assets & $\begin{array}{l}\mathbf{- . 0 2 0 0 5 8 7} * * * \\
(.0014112)\end{array}$ & $\begin{array}{l}\mathbf{- . 0 2 0 1 0 7 7} * * * \\
(.0014119)\end{array}$ \\
\hline Capital Expenditures & $\begin{array}{l}\mathbf{. 0 4 1 8 5 4 1} * * * \\
(.0028936)\end{array}$ & $\begin{array}{l}\mathbf{. 0 4 1 8 7 7 4} * * * \\
(.002895)\end{array}$ \\
\hline$R \& D$ & $\begin{array}{l}. \mathbf{0 0 6 0 6 9 6} * * * \\
(.0003356)\end{array}$ & $\begin{array}{l}.0060779 * * * \\
(.0003357)\end{array}$ \\
\hline Free Cash Flow & $\begin{array}{l}.0199342 * * * \\
(.0014114)\end{array}$ & $\begin{array}{l}-.0199831 * * * \\
(.001412)\end{array}$ \\
\hline Foreign & $\begin{array}{l}-.2768188 \text { **** } \\
.0148707)\end{array}$ & $\begin{array}{l}-.1846995 \text { *** } \\
(.012011)\end{array}$ \\
\hline Constant & $\begin{array}{l}\mathbf{1 . 6 0 4 3 4 6 * * *} \\
(.0500287)\end{array}$ & $\begin{array}{l}\mathbf{2 . 0 5 0 7 6 6 * * *} \\
(.0263607)\end{array}$ \\
\hline Number of Observations & 113,392 & 113,392 \\
\hline $\begin{array}{l}\text { R-Squared } \\
\text { Probability > F }\end{array}$ & $0.2789 * * *$ & $0.2782 * * *$ \\
\hline$* \mathrm{p}<0.10, * * \mathrm{p}<0.05, * * * \mathrm{p}<0.01$ & 0 & 0 \\
\hline
\end{tabular}


Table 2.

\begin{tabular}{|c|c|c|}
\hline & 1 & 2 \\
\hline \multicolumn{3}{|l|}{ Independent Variables } \\
\hline \multirow[t]{2}{*}{ Corporate Governance } & $.74794 * * *$ & $.7339372 * * *$ \\
\hline & (.0378266) & $(.0375532)$ \\
\hline \multirow[t]{2}{*}{ Foreign Private Issuer } & $-.4283961 * * *$ & \\
\hline & $(.0940136)$ & \\
\hline \multirow[t]{2}{*}{ Corp. Tax Rate } & $-.10995 * * *$ & $-.108537 * * *$ \\
\hline & $(.0045648)$ & .0045782 \\
\hline \multirow[t]{2}{*}{ Size } & $.1569323 * * *$ & $.1534972 * * *$ \\
\hline & $(.0115059)$ & (.011407) \\
\hline \multirow[t]{2}{*}{ Leverage } & .0011362 & .0011472 \\
\hline & $(.0011388)$ & $(.0011314)$ \\
\hline \multirow[t]{2}{*}{ Return on Assets } & $1.798085 * *$ & $1.855655^{* *}$ \\
\hline & $(.9147356)$ & $(.9115454)$ \\
\hline \multirow[t]{2}{*}{ Capital Expenditures } & $-1.756337 *$ & $-1.813343 * *$ \\
\hline & (.901389) & $(.89826)$ \\
\hline \multirow[t]{2}{*}{$R \& D$} & .0038795 & .0038765 \\
\hline & $(.0050802)$ & $(.0051233)$ \\
\hline \multirow[t]{2}{*}{ Free Cash Flow } & $-1.796318 * *$ & $-1.853902 * *$ \\
\hline & $(.914722)$ & $(.9115324)$ \\
\hline Constant & $1.604346^{* * * *}$ & $-5.955259 * * *$ \\
\hline Number of Observations & 127,590 & 127,590 \\
\hline Pseudo R2 & $0.4274 * * *$ & $0.4204 * * *$ \\
\hline \multicolumn{3}{|l|}{ Probability $>$ F } \\
\hline$* \mathrm{p}<0.10, * * \mathrm{p}<0.05, * * * \mathrm{p}<0.01$ & 0 & 0 \\
\hline
\end{tabular}


